Portland State University

PDXScholar

11-30-1995

\title{
American Students' Expectations of Teachers in the Japanese Language Classroom
}

Nariyo Kono

Portland State University

Follow this and additional works at: https://pdxscholar.library.pdx.edu/open_access_etds

Part of the Bilingual, Multilingual, and Multicultural Education Commons Let us know how access to this document benefits you.

\section{Recommended Citation}

Kono, Nariyo, "American Students' Expectations of Teachers in the Japanese Language Classroom" (1995). Dissertations and Theses. Paper 5261.

https://doi.org/10.15760/etd.7134

This Thesis is brought to you for free and open access. It has been accepted for inclusion in Dissertations and Theses by an authorized administrator of PDXScholar. Please contact us if we can make this document more accessible: pdxscholar@pdx.edu. 
THESIS APPROVAL

The abstract and thesis of Nariyo Kono for the Master of Arts in TESOL were presented November 30, 1995, and accepted by the thesis committee and the department.

COMMITTEE APPROVALS.
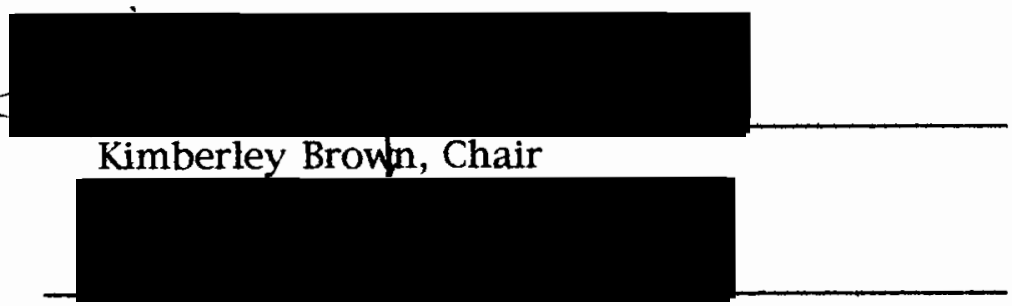

David Ritchie

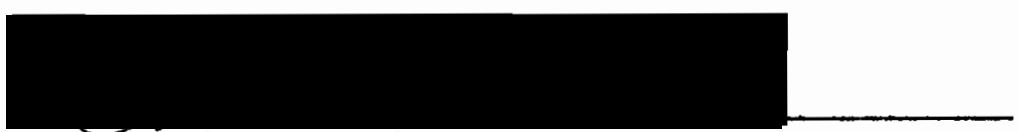

Suwako Watanabe
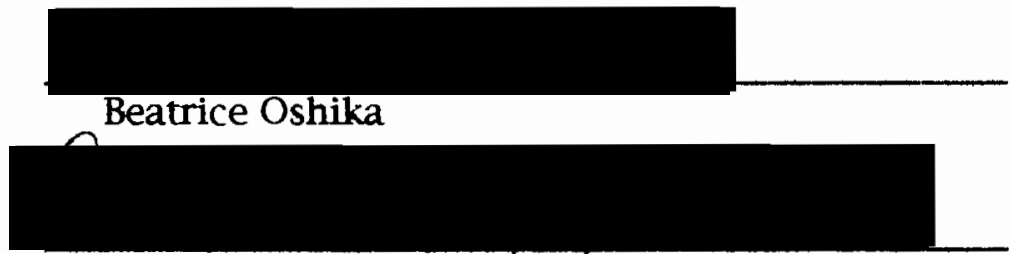

Dalton Miller-Jones

Representative of the Office of Graduate Studies

DEPARTMENT APPROVAL:

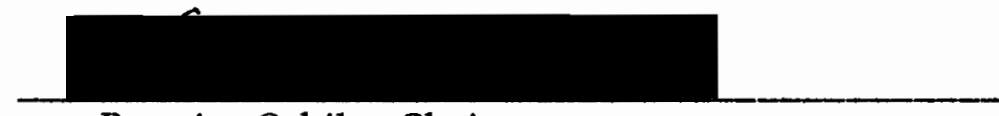

Beatrice Oshika, Chair

Department of Applied Linguistics

ACCEPTED FOR PORTLAND STATE UNIVERSITY BY THE LIBRARY

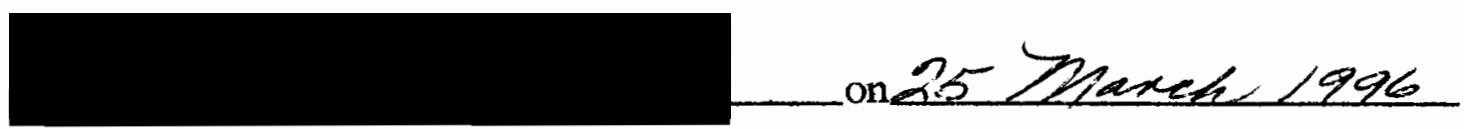




\section{ABSTRACT}

An abstract of the thesis of Nariyo Kono for the Master of Arts in TESOL presented November 30, 1995.

Title: American Students' Expectations of Teachers in the Japanese Language Classroom

The Japanese as a foreign language classroom in the United States is full of information about the target culture and cross-cultural interaction between American students and Japanese instructors. This cross-cultural interaction promotes culture learning but sometimes produces potential conflicts due to American students and Japanese instructors having different expectations of each other.

The purpose of this study was to investigate student expectations of their Japanese teachers and to explore similarities and differences among Japanese and American expectations. The research questions addressed were 1) What do American students expect of their Japanese teachers in the Japanese language classroom? Do their expectations have any distinctive features?, and 2) What do Japanese teachers expect of themselves in the Japanese language classroom? Do their expectations have any distinctive features?

The data was gathered in the two Japanese programs at universities in the Northwest. This exploratory study used both the quantitative and descriptive research methods. There were three primary data analysis procedures: multidimensional scaling analysis, hierarchical cluster analysis, and rank-order analysis. These multidimensional and hierarchical clustering 
analyses explored the underlying structure of the concept of what makes a good Japanese language teacher. The rank-order analysis revealed which beliefs were most important for different groups' judgments of who is a good teacher. In addition, the results of these analyses were discussed with the subjects through interviews.

The results suggested a major similarity and also some culture differences. Both Americans and Japanese seemed to share a very basic framework about what makes a good teacher, which contained three domains: Classroom management, Interaction and Personality. However, some of the results seemed to reflect a difference between the role-specific aspects of Japanese society and the individualistic elements of American society. In addition, the rank-order analysis seemed to reveal a difference between the two schools. 
AMERICAN STUDENTS' EXPECTATIONS OF TEACHERS

IN THE JAPANESE LANGUAGE CLASSROOM

by

NARIYO KONO

A thesis submitted in partial fulfillment of the requirements for the degree of

MASTER OF ARTS

in

TESOL

Portland State University

1996 


\section{ACKNOWLEDGMENTS}

I am grateful to my adviser, Dr. Kimberley Brown for her broadminded and continuous support in my academic and personal growth. I am also grateful to Dr. Beatrice Oshika for her unfailing support. This thesis would not exist without my having taken their classes and having their mentorship.

I would like to thank Dr. David Ritchie for his generous support on my research methodology, and Dr. Leslie Good for her service on my preliminary committee. I would like to thank Dr. Suwako Watanabe for her favorable and constant support both on my preliminary and final oral committee. I also would like to thank Dr. Dalton Miller-Jones for his warm support.

This thesis could not exist without the generous support of Dr. Patricia Wetzel, Dr. Kazuko Ikeda, Wes Brenner and the inspirational support of all the Japanese teachers and students in the programs. My appreciation goes to my friends with whom I have carried a friendship project: Jay Peterson, Masami Nishishiba, and Eriko Maeda. Thanks also goes to all my friends. Thank you Linda, Julie, Jay, Yoshiko, Miki, Bill, Michiyo and Nancy for your emotional support.

Finally I would like to thank my parents in Japan and my host families in the U.S. for their unconditional love and support. トターシャ、ミターシャ、本当 にありがとう!

This thesis is dedicated to my parents, all my teachers, students who are eager to learn languages and teachers who are also willing to help them. 
TABLE OF CONTENTS

PAGE

CHAPTER

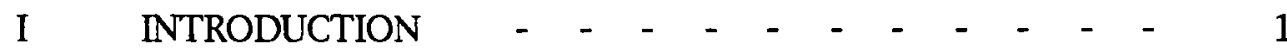

II BACKGROUND RESEARCH - - - - - - - - - 6

Transformative Learning - $\quad-\quad-\quad-\quad-\quad-\quad 6$

Culture and Language Teaching - $\quad-\quad-\quad-\quad 8$

Culture and the Self -

The classroom in the U.S. and Japan - - - - 12

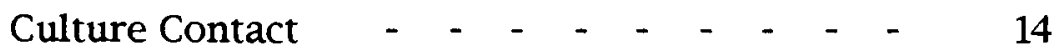

Culture Contact in the Language Classroom - 16

Teacher Quality and Evaluation - - - - - 18

Summary of the Literature Review _ - - 21

III METHODS - - - $^{-}$-

Multidimensional Scaling $\quad-\quad-\quad-\quad-\quad-\quad 22$

Hierarchical Cluster Analysis - - - - $\quad 27$

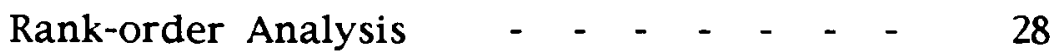

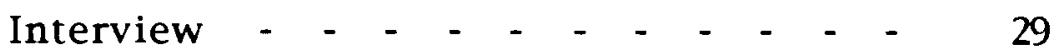

DATA $\quad-\quad-\quad-\quad-\quad-\quad-\quad-\quad-\quad-29$

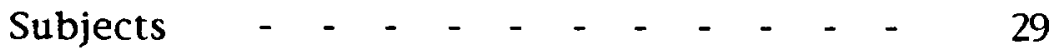

The Two Japanese Programs - $\quad-\quad$ - $\quad 30$

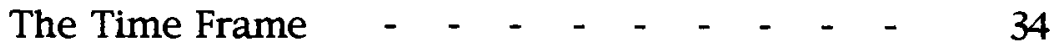

PROCEDURES $\quad-\quad-\quad-\quad-\quad-\quad-\quad-\quad-\quad-35$

Pilot Study for Pre-Study - - $\quad$ - $\quad$ - $\quad$ - $\quad$ - $\quad 36$

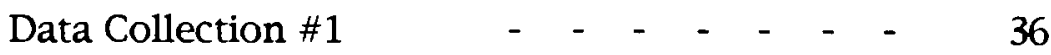

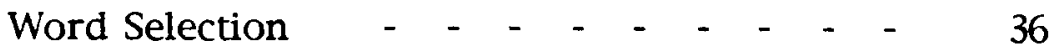


Pilot Study for Main Study $\quad-\quad-\quad-\quad-\quad-\quad 37$

Data Collection \#2 - -5 - $\quad$ - $\quad$ - $\quad$ - $\quad$ - 38

Data Collection \#3 -

IV DATA ANALYSIS - $-{ }_{-} \quad-\quad-\quad-\quad-\quad-\quad 41$

Multidimensional Scaling $\quad-\quad-\quad-\quad-\quad-\quad 42$

Hierarchical Cluster Analysis - - - - - 46

Comparison of American and Japanese Maps - 48

Rank-order Analysis - $\quad-\quad$ - $\quad$ - $\quad$ - 57

V INTERVIEWS AND INTERPRETATIONS - - - - - 62

Interpretation of Word-clustering by

Hierarchical Cluster Analysis - $\quad$ - $\quad$ - $\quad 62$

Interpretation of the Dimensions on the MDS-maps 66

Interpretation of the Rank-order Results - 68

General Comments on Japanese Classes

and Teacher-Student Interaction $\quad-\quad-\quad 70$

Summary of the Interpretation and Discussion $\quad 70$

VI CONCLUSIONS AND DIRECTIONS FOR FUTURE RESEARCH

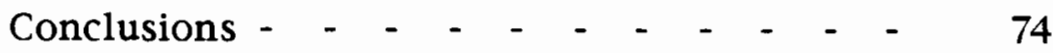

Implications for the Language Classroom - $\quad 75$

Limitations of the Study $\quad-\quad-\quad-\quad-\quad-\quad 76$

REFERENCES $\quad-\quad-\quad-\quad-\quad-\quad-\quad-\quad-\quad-\quad-\quad-\quad-\quad-\quad-\quad 78$

APPENDIX $\quad-\quad-\quad-\quad-\quad-\quad-\quad-\quad-\quad-\quad-\quad-\quad-\quad 86$ 


\section{CHAPTER I}

\section{INTRODUCTION}

Culture learning is a major component of most foreign language teaching. The Japanese as a foreign language classroom in the United States is full of information about the target culture and cross-cultural interaction (culture contact) between American students and Japanese instructors. This culture contact promotes culture learning but sometimes produces potential conflicts due to American students and Japanese instructors having different beliefs and values about teacher-student interaction, and they having different expectations of each other. These beliefs are embedded in their different cultures, Japanese and American. They include beliefs about the value of education, the role of the teacher, and classroom organization (Nelson \& Brown, in preparation). There have been many cross-cultural studies of the U.S. and Japan in the literature (Markus \& Kitayama, 1991; Cousins, 1989; Hofstede, 1986, etc), but it is not clear from these studies how their results could be applied to the language learning classroom. Even though there are rich resources about classroom culture in minority and refugee studies (Spindler, 1987; Ogbu, 1987; Gibson, 1987), there is much less research on the process of learning classroom culture in teaching ESOL (English to speakers of other languages) or foreign languages. Nieto (1992) states the importance of the cultural study as follows:

Research of this kind is important if we are to grasp how children from different cultural backgrounds respond to teachers' behaviors and what teachers can do to change the unconscious messages they may be sending to their students. (Nieto, 1992, p. 118) 
The purpose of this research is to investigate student expectations of their Japanese language classes and to explore similarities and differences among teacher and student expectations. There were three primary data analysis procedures: multidimensional scaling analysis, hierarchical clustering analysis, and rank order analysis. The multidimensional and hierarchical clustering analyses explored the underlying structure of the concept of what makes a good Japanese language teacher as interpreted by American students and by Japanese teachers. The rank order analysis revealed which beliefs were most important for different groups' judgments of who is a good teacher. Multidimensional scaling and hierarchical cluster analysis are mathematical tools used to describe students' and teachers' conscious and unconscious criteria for making judgments. The spatial maps can be used to provide visual images which can be used in turn to determine differences in perceptions. If there is any difference between American students and Japanese instructors represented by these maps, it would mean that students' perceptions of teachers are different from the instructors'. The difference could then be considered for classroom management. If there is no difference between them, then American students have the same perceptions as Japanese instructors. These similarities and differences of perceptions are conceptualized in terms of Mezirow's (1990) "transformative learning" theory. This theory is based on the presuppositions on which our beliefs have been built. Mezirow (1990) defines learning as "the process of making a new or revised interpretation of the meaning of an experience, which guides subsequent understanding, appreciation, and action" (p. 35). Mezirow explains learners' old schemata as habits of expectation:

What we perceive and fail to perceive and what we think and fail to think are powerfully influenced by habits of expectation that 
constitute our frame or reference, that is a set of assumptions that structure the way we interpret our experiences. (p.1)

Mezirow (1990) points out that individuals see the world through their own unique perceptual lenses. For learners this means that what they experience may not be what the teacher thinks that they experience. Therefore, in the language classroom the product of self and other perceptions could be a key to successful culture teaching. Kramsch (1993) believes that language teachers should "replace the presentation/prescription of cultural facts and behaviors by the teaching of a process that applies itself to understanding foreignness or otherness" (p.206). How to deal with learners' consciousness or awareness is a critical issue in language and culture learning.

My teaching experiences as a language teacher and experience living in the U.S. as a second language learner have made me aware of the importance of including culture teaching in the language classroom. Sometimes I have encountered miscommunication with my students in our classes and also have had some communication problems in daily life. However, most of the problems could not really be solved because nobody could give objective explanations for them. These problems could have been cultural, personal, or situational. Therefore, I conducted this exploratory study with quantifiable tools that can describe the phenomena of the language classroom.

The research method of this study is both quantitative and descriptive. Another characteristic of this research is that this study is method-driven. There are not many quantifiable research methods that can describe social phenomena such as the classroom situation, or describe teaching activities or teacher-student interaction as a system. Therefore, I explored a couple of 
methodologies that can be used to study the classroom situation. One of the most difficult tasks for researchers in the classroom is how to limit variables because there are so many variables in the classroom situation. Teaching methodology is one of these variables. Methodology can differ in many ways, particularly in how the classroom activities are structured (i.e., whether group activities are used, whether the class is teacher-centered or studentcentered, how teachers and students interact, etc.). In order to resolve these compound variables, two Japanese programs that have different teaching methods will be examined in this research. One is the Japanese program at a public university and the other is at a private university. Both universities are large universities in the Pacific Northwest. In this paper, the public university is called "Northwest State University," and the private university is called "Sylvan University" as pseudonyms in order to maintain their privacy.

\section{RESEARCH QUESTIONS}

1. What do American students expect of their Japanese teachers in the Japanese language classroom? Do their expectations have any distinctive features?

2. What do Japanese teachers expect of themselves in the Japanese language classroom? Do their expectations have any distinctive features?

3. What are the differences between American students' expectations and Japanese teachers' expectations?

4. Do American students' expectations change over time and how? (alternative) 
4. Is there any relationship between students' expectations and their learning factors: language level (four groups: through the first year to the fourth year), age difference, gender difference, experience of living abroad, preference for teaching methodology, etc.?

5. Is there any relationship between teachers' expectations and their teaching factors: teaching experience, experience of living abroad, age difference, etc.? 


\section{CHAPTER II \\ BACKGROUND RESEARCH}

This chapter covers some of the background research that gave insight and depth to this research. Markus \& Kitayama's (1991) concept of self and others, Mezirow's (1990) transformative learning theory, and Amir's (1969) contact hypothesis were introduced as basic concepts to this research. In addition, some of the comparative studies between the U.S. and Japan were presented. The teacher evaluation section was added in order to give an additional reference to the study.

\section{Transformative Learning (Habit of Expectation)}

Mezirow (1990) defined learning as "the process of making a new or revised interpretation of the meaning of an experience" (p. 1). People have habits of expectations, that is, "a set of assumptions that structure the way we interpret our experiences" (p. 1). Those habits of expectations are influential over people's perceptions and play an important role in interpreting meaning.

There are two structures associated with meaning: meaning schemes and meaning perspectives. Meaning schemes are basic assumptions for simple sequences or cause-effect relationships. For example, people know that food satisfies our hunger, and that the sun will rise in the east and set in the west. On the other hand, meaning perspectives are made up of "higher-order schemata, theories, prepositions, beliefs, prototypes, goal orientations and 
evaluations" (p.2). The meaning perspectives predict and establish loverbeloved, teacher-student, employer-employee and the other role relationships involving habitual expectations, which provide the presuppositions on which people make interpretations and take action. For the most part, meaning perspectives are "uncritically acquired in childhood through the process of socialization, often in the context of an emotionally charged relationship with parents, teachers, or other mentors" (p. 3). Those consciously and unconsciously acquired higher-order schemata involve "criteria for making value judgments and for [establishing] belief systems" (p. 2).

In teacher-student relationships, both teachers and students might bring their own meaning perspectives with old habits of expectations. However, perspective transformation, a culture assimilation, might occur such as in the process of critical reflection. Mezirow (1990) emphasized critical self-reflection as one of the most significant learning experiences in adulthood, that is, "reassessing the way we have posed problems and reassessing our own orientation to perceiving, knowing, believing, feeling, and acting" (p. 13). Furthermore, Mezirow (1990) claimed that making learners aware of psychocultural assumptions is the most effective way of learning:

Perhaps the most significant kind of adult learning involves bringing psychocultural assumptions into critical consciousness to help learners understand how they have come into possession of conceptual categories, rules, tactics, and criteria for judging that are implicit in their habits of perception, thought, and behavior. (p. 361)

In addition, Mezirow (1990) emphasized the importance of knowing learners' fundamental needs as an educator's responsibility. Mezirow's fundamental idea about learning is as follows: "Learning is not a desirable 
outcome or a goal; it is the activity of making an interpretation that subsequently guides decision and action. Learning is grounded in the very nature of human communication" (p. 373). Learning should be captured as a process of making interpretations and every learner's stage can be assessed in terms of meaning schemes and meaning perspectives involving habits of expectations. Culture learning in the language classroom can also be captured as a process of making interpretations. In this research habits of expectations of American students and Japanese instructors in the language classroom were explored.

\section{Culture and Language Teaching}

In language teaching, culture plays a very important role because culture underlies every aspect of life. Hall (1959) says, "culture controls behavior in deep and persisting ways, many of which are outside of awareness and therefore beyond conscious control of the individual"(p.25). This explains the reason why people sometimes experience culture shock or reentry culture shock, which can be a severe feeling when she/he encounters very different norms or value systems from their own. Those experiences might happen because people's value systems are unconsciously embedded in each society. Usually people do not notice the various norms or systems until they encounter different value systems from their own. Shweder \& LeVine (1984) define culture as "a shared organization of ideas that includes the intellectual, moral, and aesthetic standards prevalent in a community and the meanings of communicative actions." This shared organization of ideas is invisible, and varies from one to another. Kramsch (1989) says, "different countries have different political cultures, different intellectual styles, 
different societal fears, hopes, prides, different meanings and values attached to language and culture themselves" (p.1). To be communicatively competent in a language, not only linguistic, but also cultural and educational goals are required. Furthermore, Kramsch claims that sociolinguistic competence has been identified as a key aspect of successful communication.

In addition to Kramsch, many researchers in TESOL refer to the relationship between culture and language, and the sociocultural aspects of language teaching (Brown, 1987; Scarcella \& Oxford, 1993; Bachman, 1990; and Damen, 1987). According to Scarcella \& Oxford (1993):

Today, investigators are more interested in determing how individuals differ from one another, both in terms of their inherent potential for mastery of discourse competence and in terms of the extent to which their culture provides models and incentives for acquiring this competence. (p.52)

"Culture learning is an ongoing, dynamic process in which learners' cultural perception can change, unfold, and mature over time" (Scarcella \& Oxford, 1993). During the process of language learning, the value system of the native language and society always confronts that of the target language and society regardless of the learners' conscious awareness.

This point of view towards culture is especially emphasized in the foreign language teaching pedagogies. In one Japanese teaching methodology, Jorden (1992) calls this value system, which natives acquire subconsciously as they are socialized within their native society, "mind-set." In addition, she emphasizes that "rather than language and culture, it is language in culture that should be our concern..." (p.145). Furthermore, other foreign language educators also emphasize the importance of teaching culture in the language classroom. Kramsch (1993) states the importance of culture teaching as following: 
If, however, language is seen as social practice, culture becomes the very core of language teaching. Culture awareness must then be viewed both as enabling language proficiency and as being the outcome of reflection on language proficiency. (p.8)

Another educator, Byram (1990), considers language learning, language awareness, cultural awareness, and cultural experience as independent sectors but also as mutually supportive and requiring balance. How to deal with learners' consciousness or awareness is a major issue in language and culture learning. Byram (1990) claims that "the cultural awareness component is also concerned with non-linguistic dimensions of culture and more focused on the question of change from monocultural to intercultural competence" (p.24). Kramsch (1993) thinks that language teachers should "replace the presentation/prescription of cultural facts and behaviors by the teaching of a process that applies itself to understanding foreignness or otherness" (p.206). Kramsch considers teaching culture as an interpersonal process. Understanding of self and other perceptions could be a key to successful culture teaching in the language classroom.

\section{Culture and the Self}

Markus \& Kitayama (1991) suggested that people in different cultures have different construals of the self, of others, and of the interdependence of the two, which could influence individual cognition, emotion, and motivation. According to them, many Asian countries, including Japan, have "concepts of individualities that insist on the fundamental relatedness of individuals to each other," with an emphasis on "attending to others, fitting in, and 
harmonious interdependence with them"(p. 224) This concept is labelled an interdependent view of the self. Other labels for this view include "sociocentric, holistic, collective, allocentric, ensembled, constitutive, contextualist, connected, and relational" (p. 226) On the other hand, American individuals seek interdependence from others without assuming or valuing an overt connectedness among individuals, which is called an independent view of the self. Other connotations for this concept include "individualist, egocentric, separate, autonomous, ideocentric, and self-contained" (p. 226)

These thoughts of self and other are conceptualized in terms of "selfrelevant schemata" (Markus \& Kitayama, 1991, p.230). This self system could be instrumental in the regulation of intrapersonal and interpersonal information processing, which guides people's thoughts and actions, cognition, emotion, and motivation. For example, Cousins (1989) found that Japanese responded more to context-specific knowledge of the self and other, whereas Americans responded more in the context-free situation. For emotion, Markus \& Kitayama (1991) claimed that the people who hold independent view tend to have ego-focused emotions, whereas interdependent view driven people have other focused emotions.

For motivation, the people who hold the 'independent view' possess internal and individually rooted motives -- "the motive enhance one's self-esteem, the motive to achieve, the motive to affiliate, the motive to avoid cognitive conflict, or the motive to self-actualize" (p. 239). On the other hand, the 'interdependent view' might suggest many social motives such as "the need to admire and willingly follow a superior, ... the need to nourish, aid, or protect another,.. the need to seek aid, projection, or sympathy..." (p. 240). 
Other research on socialization seems to support these different construals of the self, of others and of the interdependence of the two. White (1987) concluded from her long-term observations of Japanese education in comparison with American education that "Japanese children are always assured of support, exhortation, and devotion from their parents, school, and the society at large, but especially from their mothers" (p. 185).

However, a recent study reported some specific changes concerning the child in modern Japanese society and overall loss of balance within the traditional view. (Befu, 1986) Rosenberger (1989) pointed out that the false dichotomies between individual and society, and Western versus non-Western have been easily created by Western trained scholars of Japan. Rosenberger proposed an attempt to convey the complex processes involved in the relationships between the self and the social in Japan. "The study of Japanese concepts of self helps us as Western-trained scholars to understand the self as firmly embedded in culturally constructed world" (Rosenberger, 1989, p. 4).

\section{The Classroom in the U.S. and Japan}

A tremendous amount of research has been done on the classroom in the fields of education, anthropology, sociology, and psychology. Most of the research on classroom culture has been described from an ethnographic point of view, but some of the research has described classroom culture from several different points of view (Spindler, 1987; Ogbu, 1987; Gibson, 1987; Bossert, 1979; Hamilton \& Sanders, 1992, and Rohlen, 1983). Some attempts have been made to grasp the differences in teaching practices in the classroom among several different countries using cross-cultural and cultural psychology based on culture practice theory (Rogoff, 1981 and Scribner \& Cole, 1981). 
The following research (Stinger \& Stevenson, 1992) focused on crosscultural differences in schooling. Their method of research is descriptive rather than experimental, providing description from observations. In addition, the level of activities that they observed seems to be more precise with less attention placed on cognitive level- activities in the traditional sense.

Stingler and Stevenson (1992) examined the practices and goals of schooling in American, China, and Japan. According to their results, the processes and outcomes of schooling in these three societies reflect deeply held cultural values. "These values influence the practices and expectations that children encounter in school" (p.208). They pointed out that "there was frequent verbal interaction in the classroom as the teacher attempts to stimulate students to produce, explain, and evaluate solutions to problems" (p.209) in Asian schools, and explained how this contradicts Westerners' stereotypes of Asian teaching practices. There are some big differences between American and Asian schooling practices. American teachers spend more time in transition and less in academic activities. In their observation:

the teacher interrupted the flow of the lesson with an interlude of irrelevant comments or the class was interrupted by someone else in 20 percent of all first-grade lessons and 47 percent of all fifth-grade lessons. This occurs less than 10 percent of the time at both grade in Sendai (Japan), Taipei (Taiwan), and Beijing (China). (p.211)

In addition, American teachers shift topics frequently within the lesson in order to capture children's interest, whereas "Asian teachers also seek variety but they tend to introduce new activities instead of new topics" (p.211).

According to Stingler \& Stevenson, "elementary school classrooms [in general] are organized in one of three ways: the whole class is working as a unit; the class is divided into a number of small groups; or children work individually" (p.211). They observed the percentage of time students spent in 
activities led by a teacher and led by no one. One of their significant findings is that Asian students received much more instruction from their teachers than American students. No one was leading instruction 9 percent of the time in Taiwan, 26 percent of the time in Japan, and 51 percent of the time in the U.S.

In order to seek the cause of these differences, Stingler and Stevenson consider that there must be some different cultural beliefs behind how American and Asian teachers try to handle diversity in their classes:

While American schools attempt to solve the problems of diversity by segregating children into different groups or different classrooms, and by spending large amounts of regular class time working with individual students, Asian teachers believe that the only way they can cope with the problem is by devising teaching techniques that accommodate the different interests and backgrounds of the children in their classrooms. (p.214)

\section{Culture Contact}

In the language classroom the teacher-student relationship promotes the interpersonal process with respect to teaching or learning culture by communicating with each other. In addition, this on-going (teacher-student) relationship enhances the intercultural process between the native and the target culture as well as the interpersonal process. Nieto (1992) says:

Culture is not simply what children bring to school, however. Teachers, too, have a culture and approach their teaching roles with their own experiences and philosophy about the nature of teaching and learning. (p.117)

Thus, teacher-student interactions produce rich culture contact in the language classroom. This culture contact might change people's attitude in ethnic relations. Amir (1969) concludes that "contact between members of 
ethnic groups tends to produce changes in attitude between these groups" (p.338). He suggests his contact hypothesis as follows:

The direction of the change depends largely on the conditions under which contact has taken place; "favorable" conditions tend to reduce prejudice, "unfavorable" ones may increase prejudice and intergroup tension. (p.338)

In other words, the teacher-student relationship might reduce or increase prejudice depending on the conditions. According to Amir, there are several conditions that are considered "favorable" such as when there is equal status contact between the members of the various ethnic groups, when the contact is of an intimate rather than a casual nature, or when the ethnic intergroup contact is pleasant or rewarding. On the other hand, "unfavorable" conditions occur when the contact situation produces competition between the groups, and when the contact is unpleasant, involuntary or tension laden. These factors also underlie the teacher-student relationship. "Favorable" conditions might lead to the learners' positive attitudes toward learning language and culture, whereas "unfavorable" conditions might cause some problems between the teacher and the student. Consequently, ethnic (culture) contact does not always result in positive intercultural relationship. The same can be said in a foreign or second language classroom. Amir (1976) suggested an approach for this issue as follows:

Some of these alternatives could be based on our knowledge of psychology or sociology, but solutions should also be looked for in economics, education, or any other discipline involved in social change and planning. (p. 294)

Amir (1969) also suggested "reconsidering and retesting the expectations [of intergroup] improves the understanding between groups" (p. 340). The language classroom also can be examined through Amir's perspectives. 


\section{Culture Contact in the Language Classroom}

Teacher-student interactions include various activities that are embedded in culture. If teachers are culturally different from students, they have disadvantages in their educational planning because they frequently lack a close knowledge of the students' previous learning. The language classroom is a good example of this. Teacher-student interaction in the language classroom frequently produces some problems between teachers and students because both expect different activities and behavior based on their own cultural beliefs. According to Scarcella \& Oxford, "Most puzzling and problematic for many ESL students are the interactional styles of Anglo-American teachers" (Scarcella \& Oxford, 1993, p. 52).

Nelson \& Brown (in preparation) investigated cultural differences in educational practices, values, and beliefs among ESL students (257 Japanese, 131 Korean, 80 Taiwanese, and 53 Chinese) at U.S. universities. In their comparison of pedagogical practices in the U.S. and Japan, Korea, Taiwan, and the People's Republic of China, Nelson \& Brown suggest that one area of possible conflict concerns cultural differences in teacher-centered vs. student-centered education. One of their findings was that "six items (student vs teacher decision-making, teacher vs. student direction, appropriateness of students criticizing teachers, preference for order vs. creativity, and conditions under which student talk in class) had small but significant correlation with each other, suggesting the items may loosely measure classroom operationalizations of power distance for Japanese students" (p. 6). Hofstede (1986) defines power distance as "a characteristic of a culture defines the extent to which the less powerful persons in a society accept inequality in power and consider it as normal" (p. 306). 
Rhee and Watanabe (1993) analyzed American students' verbal behavior in the Japanese language classroom based on examples from interviews. According to their list of examples, American students use casual greetings and expressions to the instructor, express dissatisfaction, complain or point out problems to the instructor directly, and make excuses. All of these are considered inappropriate student behavior in school settings. Therefore, a Japanese instructor may be bewildered when an American student comes to the office to negotiate a grade on the exam because negotiation with teachers does not occur in Japan. In addition to verbal interaction, nonverbal behavior of American students may not be familiar to Japanese instructors. For example, eating in the classroom, waving to the instructor when greeting her outside of class, wearing baseball caps and hats in the classroom, and throwing or sliding material onto the teacher's desk are considered lack of respect on the part of a student in the Japanese classroom. Japanese and Korean teachers may react to these behaviors negatively because they have been trained differently in their society. One solution suggested by Rhee \& Watanabe (1993) is to address the issue of cross-cultural differences in the teacher/student role expectation during teacher training.

Jin \& Cortazzi (1993) studied the features of the cultural orientation of 101 Chinese post-graduate students and visiting scholars studying in Britain and compared them with the cultural orientation of 37 British academic staff through questionnaires and interviews. They found some misunderstanding on both sides and concluded it was likely because of "a lack of explicit cultural awareness of both of their own and the other culture" (p. 95). Chinese students expected British tutors to guide them, to know everything, and to be moral leaders. On the other hand, British staff expected the students to think 
for themselves, to know what to do and to develop independence, individuality, and creativity. Jin \& Cortazzi (1993) claimed that mutual cultural knowledge and awareness could have prevented many of the problems, and suggested that the practice of "cultural synergy" between two groups would benefit students' adaptation. They explained " cultural synergy" as follows:

Cultural synergy means that people from two or more cultures interact systematically, cooperating for a common purpose with an attitude of being willing to learn, understand and appreciate the other's culture without loss of their own status, role or cultural identity. (p.95)

Culture synergy is a two-way learning process and both students and teachers learn about each other culture through teacher-student interaction in the classroom. According to Jin \& Cortazzi (1993), cultural synergy is a "tool for learning: it is the major cultural role of second language use in higher education" (p.95).

\section{Teacher Quality and Evaluation}

In discussing good qualities for a language teacher, Strevens (1987) claimed that language teachers should be aware of two necessary qualities: professionalism and instructional techniques:

The good teacher cherishes his pupils, know them, understands their individuality as learners, recognizes their learning preferences and their difficulties, and sees their language learning progress on a time scale greater than simply that of the class, the week, the semester, or the year. (p. 15)

The educator must be a good teacher, but also have a wider perspective, which enables her/him to connect teaching with the whole of students' needs and societal needs. 
Feldman (1984) developed categories for a good teacher from many different student evaluation forms at college. The following categorized items identify the characteristics of college teachers in general. These items were used to confirm the words or phrases in this study (see Appendix F). Some of the items were irrelevant for this study. Since Feldman's study was aimed at teacher evaluation, a course evaluation (no. 21) and an instructor evaluation (no. 22) were included. However, those items were not necessary for my study as the purpose was not teacher evaluation. In addition, Feldman's study did not focus on language teachers but teachers in general, whereas this study focused on language teachers. Therefore, some of the elements did overlap each other.

Table 1

Feldman's examples of items used in "Multisection validity studies, categorized into dimensions" (cited by Centra, 1993, p. 55-56)

1. Stimulation of Interest

The instructor put material across in an interesting way.

2. Enthusiasm

The instructor demonstrated dynamism and enthusiasm for the subject.

3. knowledge of the subject

The instructor had a thorough knowledge of the subject matter.

4. Preparation and Organization of the course each class period was carefully planned.

5. Clarity and Understandableness.

The instructor summarized or emphasized major points in lectures or discussions.

6. Elocutionary Skills

The instructor was clear and audible

7. Class level and Progress

The instructor seemed to know when students did not understand the material.

8. Clarity of course Objectives

The instructor's objectives for the course were clear.

9. Relevance and Value of Course Materials

Rate the extent to which the text was a useful part of the course. 
10. Relevance and Usefulness of Supplementary Materials

Overall, I would rate the supplementary readings as

11. Workload

The student had to work hard in the course.

12. Perceived Outcome

The course increased my general knowledge.

13. Fairness of Evaluation

Examinations reflected important aspects of the course.

14. Classroom Management

The students had a voice in deciding how we did what was done.

15. Personality Characteristics

Rate the instructor's sense of proportion and sense of humor.

16. Feedback

The instructor made helpful comments on papers or exams.

17. Encouragement of Discussion and Diversity of Opinions

In this class, we tried to understand points of view that differed from our own.

18. Intellectual challenge and Encouragement of

Independent Thought

This course challenged me intellectually.

19. Concern and Respect for Students

The instructor was friendly.

20. Availability and Helpfulness

The instructor was readily available for consultation, by appointment or otherwise.

21. Overall course

Rate the overall effectiveness of the course

22. Overall Instructor

How would you rate your teacher in general?

Furthermore, many factor analyses of students evaluations have been done and many similar factors have been identified such as: 1 . organization, planning, or structure; 2 . teacher-student interaction or rapport; 3. clarity, communication skill; 4. work load, course difficulty; 5. grading and examinations, assignments; and 6. student learning, student self-ratings of accomplishments or progress (Centra, 1993, p. 57).

Student evaluation of teachers could be considered the outcome of students' expectations of teachers. Therefore, the preceding literature was relevant to this study; however, research dealing with Japanese students did not exist. 
Summary of the Literature Review

Much of the literature suggested there were some differences between the U.S. and Japan. Furthermore, some of the literature implied there might be some expectation differences in teacher-student interaction between the U.S. and Japanese cultures. In this research, habits of expectation of American students and Japanese instructors in the Japanese language classroom were explored and compared. Any of the similarities or differences could be helpful in bringing insight and mutual understanding of the differences between the native and target culture. This research could describe the cross-cultural situation through teacher-student interaction as a culture learning process and contribute to cultural synergy in the language classroom. 


\section{CHAPTER III}

\section{METHODS}

Since this research is exploratory, there were no working hypotheses developed prior to the data gathering. Basically there were three primary data analysis procedures: multidimensional scaling analysis, hierarchical clustering analysis, and rank order analysis. These multidimensional and hierarchical clustering analyses explored the underlying structure of the concept of what makes a good Japanese language teacher as interpreted by American students and by Japanese teachers. The rank order analysis revealed which beliefs were most important for different groups' judgments of who is a good teacher. These are described in detail below. There were three primary data collection steps: 1. word-selecting from questionnaires asking about the concept of Japanese 'good teachers' in the Japanese classroom, 2. confirming the selected words from the literature on teacher evaluation, and 3. performing a card sorting and ranking exercise based on the selected words. These are outlined in detail throughout this chapter. The results of these analyses were discussed with the subjects through interviews.

\section{Multidimensional Scaling (MDS)}

According to Young (1987), "the term 'multidimensional scaling' (hereafter MDS) refers to a family of data analysis methods, all of which portray the data's structure in a spatial fashion easily assimilated by the relatively untrained human eye" (p. 3). MDS is a mathematical tool that 
analyzes and identifies the underlying dimensions of psychological objects as well as physical objects. "Psychological objects can be tangible, such as chairs and postcards, but they can also be almost anything that is perceived by the senses and that results in some cognitive affect" (Dunn-Rankin, 1983, p. 4). Psychological objects can be pictures, colors, words, tones, and also sentences or statements about which subjects have some perception or attitude. Those psychological objects (statements) might evoke different responses among people but still remain generally evaluative in nature or dimensionality. First, the psychological objects have to be chosen. Then, the responses to the objects must be (1) judgments of similarity or (2) choices (preferences). In order to assess people's judgments or choices about psychological objects, several tasks can be utilized: placing (grouping), naming (categorizing), ordering, quantifying, and combinations of any of these. In this study, a cardsorting exercise was used. The card-sorting exercise is one of the placing (grouping) tasks which allow the subjects to determine the similarity between objects. The number of co-occurrences between each object represents their similarity which is represented on a map as distance. Cognitive maps are constructed by building a co-occurrence matrix (see Appendix A). This cooccurrence matrix constructs a hierarchical cluster analysis as well. Hierarchical cluster analysis is outlined in detail later in this chapter.

The primary purpose of MDS is to produce a parsimonious spatial representation of the object. The method is applicable to a wide number of measures of similarity or dissimilarity and "unlike factor analysis can be used on data derived from a small number of subjects and with few assumptions about the data" (p. 190, Dunn-Rankin, 1983). Dunn-Rankin, Leton, and Sato (1972) studied Hiragana characters (Hiragana is one of Japanese writing 
systems) which were printed on disks. Adult subjects unfamiliar with the Japanese language were asked to group the letters into clusters. The resulting percentage overlap matrix shown in Table 1 was analyzed using one of the MDS techniques. A two-dimensional solution is presented with a cluster analysis superimposed on the scaling in Fig. 1.

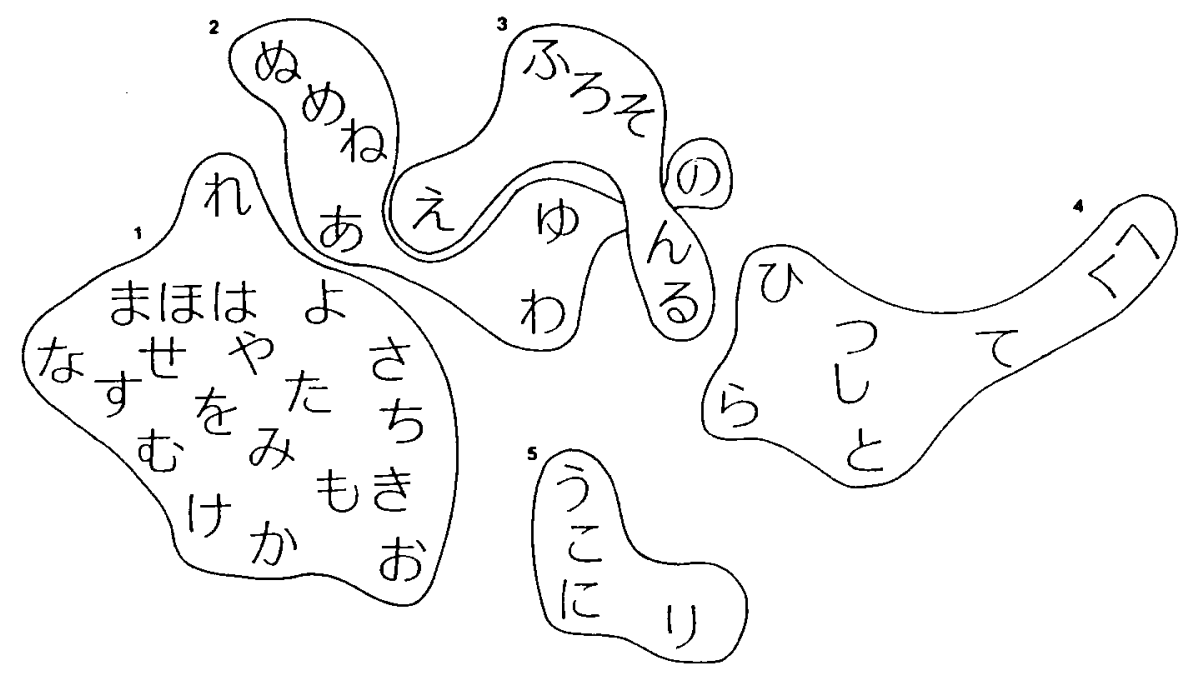

Figure 1. Multidimensional scaling of hiragana characters with divisive clustering superimposed. Data was determined by the proportion of times two characters were placed in the same cluster. Clusters are identified as (1) crossed t; (2) circular curve; (3) zigzag; (4) straight line + curve, and (5) simple curve (p.202). 
Table 2

Measures of similarity under template matching (TM) and clustering (C):

Upper triangular matrix shows congruency measures for TM; lower matrix contains proportion of time two letters were placed in the same cluster.

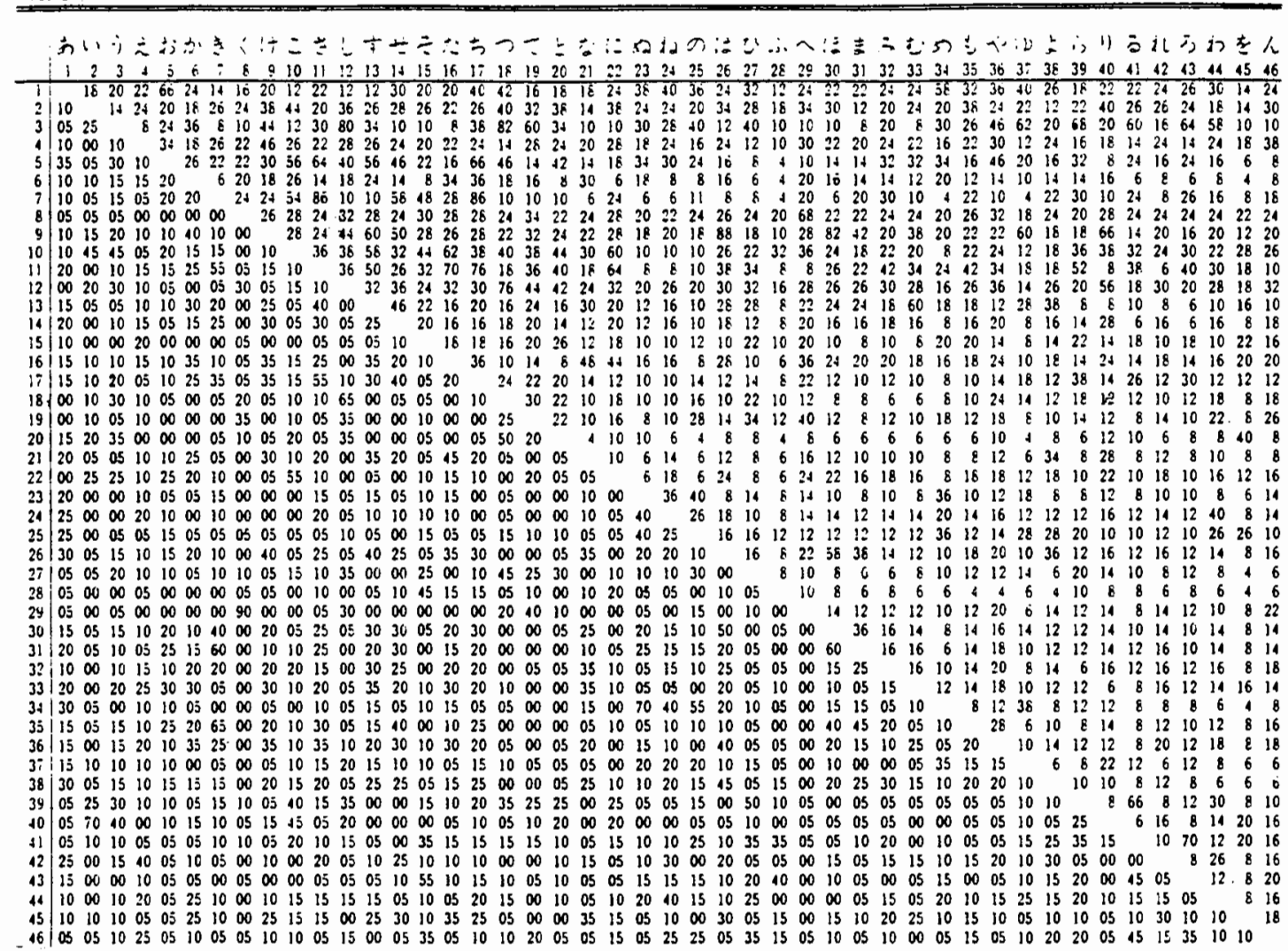

Ritchie, Baker, Good (1993) succeeded in conceptualizing subjects' interpretation of knowledge by using MDS and cluster analysis. In their study, the words or phrases associated with the meaning of knowledge were treated as objects. The MDS techniques helped to measure psychological distances among the objects and to build cognitive maps by counting co-occurrences among the words. 
In my study, the objects are the words or phrases that are associated with good teachers in the Japanese language classroom. By measuring cooccurrences among the words, MDS will plot the words and construct perceptual maps, eventually aiding in an interpretation of what makes a good Japanese language teacher.

The interpretation of the MDS maps was based on the following parameters:

1. determining the content and structure of the maps;

2. determining the number of dimensions;

3. interpreting each dimension. Each dimension represents a criterion of judgment that the subjects used to make their judgment. In order to determine the dimensionality, four considerations are relevant (Shepard, Romney, \& Nerlove, 1972):

1. The residual departure from monotonicity (stress) should not be too large or, still more pertinently, should not drop too abruptly as further dimensions are added.

2. The representation should be statistically reliable.

3. The representation should be interpretable.

4. Except in the case of special methods that do not require the rotation axes for interpretation such as INSCAL (see below), the representation should be readily visible and so confined, whenever possible, to two or, at most, three spatial dimensions. (p. 10-11)

The stress represents how much deformation the dimensional space sustains. The greater number of dimensions, the less stress. However, the greater number of dimensions, the more difficult it is to interpret the dimensional space. For example, the subjects in this study sorted the 39 cards into piles. 
That means that it could be a possibility to have 38 dimensions in space. There must be no stress in that 38 dimensional space because all the items can be plotted in any dimensional space. However, it is impossible to visualize and interpret 38 dimensional spaces. Therefore, most researchers use either a two or three dimensional solution even though the stress level is still high.

\section{Individual Differences Scaling(INDSCAL)}

This kind of MDS model assumes that different subjects perceive stimuli on common sets of dimensions. This model represents individual differences in a spatial map called the weight space. In this space individuals are represented by vectors from the origin of the space (subject weights). The weight vectors become weight points and the angles between the vectors become distances between the points when flattened (flattened subject weights)(SPSS Inc., 1992). By adding subject and flattened subject weights, it is possible to assess each subject's information as well as group information. In most cases the axes on the INDSCAL maps are not rotatable. Therefore, the dimensions themselves are meaningful.

\section{Hierarchical Cluster Analysis}

Hierarchical cluster analysis is one type of cluster analysis which forms groups of similar objects. Distance is a measure of how far apart two objects are, and closeness measures similarity. Hierarchical cluster analysis also helps to measure psychological distance among the psychological objects. The same co-occurrence matrix, by doing hierarchical cluster analysis, produces several kinds of visual representations which show distances between each word and the other word as well as a cognitive map by doing 
MDS analysis. A dendrogram is one of the representations in a hierarchical clustering solution. The dendrogram produced by SPSS does not plot actual distances but rescales them to numbers which do not correspond to actual distance values. Figure 2 shows a dendrogram for a four-beer example. The subjects sorted the four kinds of beer into groups based on their similarity.

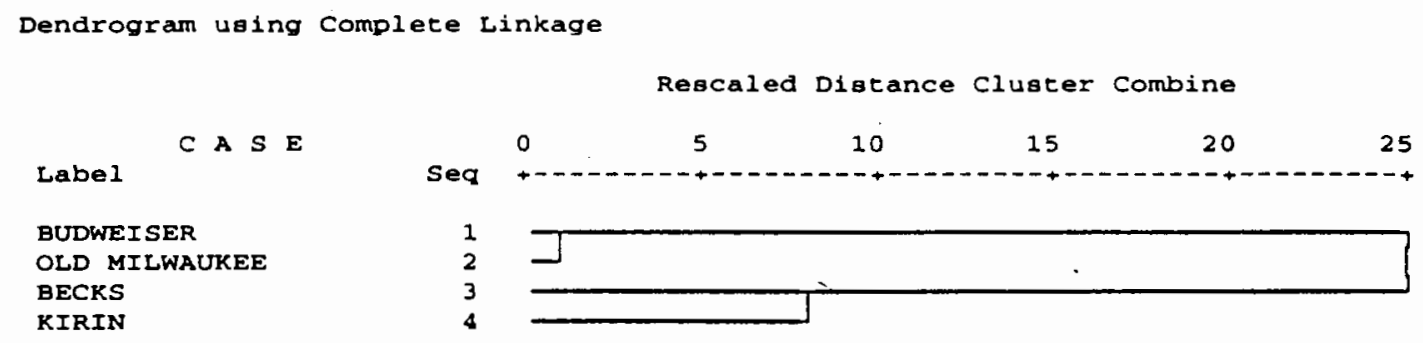

Figure 2. A dendrogram for a four-beer (SPSS Inc.,1992, p. 93) In the dendrogram above, Budweiser and Old Milwaukee were made into one cluster at one unit from the origin and Becks and Kirin were merged into another cluster at eight units for the origin. The dendrogram shows which clusters are joined and the distance at which they are joined. Combining hierarchical analysis with MDS techniques gives the researcher a more meaningful map to be interpreted.

\section{Rank-order Analysis}

In order to assess people's beliefs about what is important for judging who is a good teacher, rank-order analysis was performed. The subjects chose the five most important cards (concepts) which represented their beliefs regarding a good teacher. There were three methods used to analyze the rankordered data. First, how many times an individual card appeared among the 
group was counted and compared with the results from the following analysis. Since the subjects picked the five most important cards and ranked them, the top five cards picked were weighted from one to five points according to the ranking, and the unpicked cards were given 22 points which was an average number based on a total of 39. Lastly, based on the whole INSCAL map which included all the subjects, the coordinates (the positions on the dimensions) of the picked individual cards were taken out and weighted from five points to one point according to ranking from the top to five. Averaging the scores among the group revealed which dimension the group regarded as more important.

\section{Interview}

After interpreting these maps, a follow-up interview was conducted with about $20 \%$ of the subjects. The purpose of this interview was to confirm the content and meanings of the maps and to resolve potential confounding factors: teacher vs. students, and Japanese vs. American. The researcher showed the results to the subjects and discussed the dimensionality and possibility of the compounding factors.

\section{DATA}

\section{$\underline{\text { Subjects }}$}

The total number of subjects who participated in this research was 156 . Two Japanese programs at two different colleges provided the subject pool. One is a state university in the Pacific Northwest; the other is a private university also in the Northwest. For convenience, Northwest State University is named NSU, and the private university is called Sylvan University in this paper. At NSU, 
61 American students and 25 international students who were taking Japanese classes, twelve Japanese teachers, and eleven Japanese students who were enrolled in a teaching practicum, participated. At Sylvan University, 35 American students, ten international students, and two Japanese teachers were asked to be subjects. In addition, three American teachers at NSU and a professor and some graduate students in the TESOL and Speech Communication department at NSU participated in two kinds of pilot studies and an interview. Those details are outlined in the following section.

NSU had 61 American students (31 male and 31 female students) and 25 international students ( 9 make and 16 female students). The average age of the American students at NSU was 26.0 and of international students was 23.2. Sylvan University had 35 American students (14 male and 21 female students) and ten international students (six male and four female students). The average age of American students at Sylvan was 20.0 and of international students was 22.0. In total there were 96 American students (45 male and 51 female students) and their average age was 23.9. The total number of international students was 35 (15 male and 20 female students) with an average age of 22.9.

\section{The Two Japanese Programs}

The following examples describe the two Japanese programs based on the researcher's observation while visiting classes. All teachers' and students' names used in the following section are pseudonyms. 


\section{Northwest State University (NSU)}

NSU uses the textbook: Japanese: The Spoken Language $(1987,1988,1990)$ written by Eleanor Jorden with Mari Noda. Lessons are strongly based on oral practice at home so that class time can be spent on practices in authentic contexts. Speaking and listening are strongly emphasized, but there are also reading and writing components. NSU adopts a method of "team teaching." "Team teaching" means that American teachers are responsible for teaching grammar and cultural knowledge, whereas Japanese teachers are engaged in drill hours for oral practice. Most of the drill teachers have trained in the teaching certificate course. The textbook is written in Romanization and the students are required to listen to tapes for oral practice. In drill hours English is not allowed in the classroom.

The following example describes a typical scene in the Japanese classroom at NSU. Sato-sensei (Ms. Sato, "sensei" is a polite addressee-referent for teachers with special respect) finishes taking attendance by calling the students by their family names, and then starts to practice a mini dialogue which has been assigned for all students as homework. She shows some picture cards that indicate the content of the dialogue, and gives a model of the conversation by herself using both hands like puppets to indicate two persons. After she looks around the classroom, she calls two students' names (by family names), and says "Dozo" with a hand gesture, which means "please" but suggests that the students are to perform the dialogue. The two students perform very well but make some pronunciation errors. Sato-sensei corrects those mistakes by giving a model and having individual students repeat the same phrase. After that, she calls students' names in pairs in order to let them perform the same dialogue. Ken Gordon is in one of the third pairs to perform. 
After Ken's performance, Sato-sensei tries to correct Ken's errors. "Goodonsan, mooichido itte kudasai." (Mr. Gordon, please say it again.) Ken tries to imitate exactly Sato-sensei's pronunciation(s), but can not succeed. Satosensei calls the first two students' names to let them say the same phrase. After several more students repeat it, she calls Ken's family name again... and so on. (Both the teacher's and student's names are pseudonyms.)

\section{Sylvan University}

At Sylvan University each teacher is responsible for the entire class. That means that every teacher has his/her own teaching style and teaching curriculum. Tanaka-sensei has an activity-oriented teaching style, whereas Yoshida-sensei has a drill-centered teaching style (both to be discussed following). Tanaka-sensei (Sylvan)'s teaching style is rather similar to Satosensei (NSU)'s; however, the big difference between Tanaka-sensei and Satosensei is that Tanaka sensei uses English in the classroom. Since Tanakasensei is responsible for the entire class, she adds some grammar and culture explanations in English. The percentage of English use is about 20\% of the whole class period of time. The classroom example follows:

Tanaka-sensei distributes activity sheets to her students. The sheet has some expressions about the weather with pictures. The teacher explains in English how to do pair exercises using the weather sheet sitting on the desk. Her instruction is given mainly in English. She also writes the main structure that they will use that day on the blackboard in Japanese. During the middle of the activity, Tanaka-sensei starts to take care of one student, noticing something wrong with him immediately. Kerry is bending over pushing his stomach with his hands. "What's wrong with you?" Tanaka -sensei asked (in 
English), "Do you have a stomach ache? Do you need medicine?" "I'm all right," Kerry answers still bending over. Tanaka-sensei continues her class, occasionally asking about his condition. After letting the students practice weather expressions, Tanaka-sensei starts to explain the next activity. The students will pretend to be a broadcaster and explain the weather from various places. She uses an umbrella like a microphone and shows the example partially in Japanese but mainly in English. She asks the first student to come to the front, and gives him the umbrella...

Another teacher in the same university, Yoshida-sensei starts with oral practice of the date, day, and time. All the students answer in a loud chorus. Afterwards he gives them a short quiz and introduces a new structure that pertains to 'giving advice/suggestion' (V-ta hou ga ii desu yo.) He shows several flash cards which are written in English. The cards explain several situations, so the students try to make suggestions for the situations in Japanese. Yoshida-sensei encourages a student to provide on answer for one situation, then he repeats the correct answer and lets all the students repeat it in chorus. Mary is shown the flash card which said "broke up with boyfriend/girlfriend" in English. Some of the students responded vividly, "wow!" She had a little bit time to think, then answered, "Hana o katta hou ga ii desu yo. (You had better buy flowers.)" Yoshida-sensei acknowledges it in Japanese and starts to repeat it... 
The Time Frame

The first data collection (questionnaire) was done in the middle of February, 1995. The next data collection (card-sorting and rank-order) was performed in the middle of March, 1995. The final interview to confirm the results was conducted in the end of July, 1995. 


\section{PROCEDURES}

First, qualitative data was gathered from the subjects using an open-ended questionnaire. This data was analyzed by the researcher and several participants into 39 descriptions of words or phrases. The quantitative analyses (MDS and hierarchical cluster analysis) were performed based on the two kinds of input of the 39 words (phrases) from the subjects. Two kinds of pilot studies were intertwined with the main study. The main flow of the procedures as follows:

Pilot study for Pre-Study (to check the content of the questionnaire)

Data collection \#1 (to gather qualitative data from questionnaire) (Pre-Study)

Word selection (to choose descriptions for card-sorting)

Pilot study for Main Study (to check the descriptions on cards)

Data collection \#2 (to gather quantitative data (Main Study)

by card-sorting and rank-order exercises)

Data collection \#3 (to discuss the results (Follow-Up Study)

with the subjects through interviews)

\section{Pilot Study for Pre-Study}

The pilot study was conducted in order to examine the effectiveness of the survey and to revise it based on the results. Five people who were previously involved with the Japanese program at NSU were asked to fill out several kinds of questionnaires. Based on those observations, the instructions 
were revised and a ranking exercise that had been originally attached was dropped because of the time constraint.

\section{The Data Collection \#1 (Pre-study)}

The survey consisted of five questions asking about the concept of good teachers from different points of view (Appendix B). This was an open-ended questionnaire, and the subject completed the sentences in a word, a phrase, or several phrases. This survey format was adapted from a friendship study (Peterson, Kono, Maeda, \& Nishishiba, 1995). Japanese translation was added to this survey to aid native speakers of Japanese (Appendix C). The data was collected from several Japanese classes at NSU in the middle of February. Approximately $67 \%$ of the total number of registered students participated in this questionnaire (see Appendix D); 816 descriptions from 50 American students and 214 descriptions from 12 Japanese teachers were designated as samples.

\section{Word Selection}

First of all, from all the descriptions in the data collection \#1 (816 from American students, 214 from Japanese teachers), the words or phrases that were repeated by more than one person were selected. (Appendix E). For example, some people mentioned the same word or phrase twice in the different sentences of the same questionnaire. However, this kind of word or phrase was counted once. Also, the same word or phrase that appeared again in the negative sentence (e.g. "a good teacher should be fair." vs. "a good teacher should not be unfair.") was considered to appear only once. 
The next task was to reduce the number of the words into equal groups, so that students could sort quickly. This stage involved three steps:

1. To delete synonyms by using Roget's thesaurus.

2. To delete unnecessary words by asking 20 students to choose the most important 20 words or the least important 10 words.

3. To delete or combine some of the words by asking three American students to categorize the words based on their similarity.

For both the second and third steps, the researcher discussed the results with the subjects about the criteria for their word-choice. Based on the discussion, 39 words (phrases) were chosen.

These 39 words (phrases) were compared with the categories made by Centra $(1979,1993)$ in order to confirm appropriateness of the word choice. Fieldman devised a system for categorizing items from many different student evaluation forms. These items were discussed in the review of literature (Chapter II). A couple of the items were inappropriate for this study because of a different teaching style. For example, the phrases "Rate the overall effectiveness of the course," or "how would you rate your teacher in general?" were inappropriate because the purpose of this research was not to evaluate teachers or their course work. The rest of the contents overlapped with those of the 39 words (phrases). Appendix F shows the words that were included in the literature.

\section{Pilot Study for Main Study}

The second pilot study was conducted in order to examine appropriateness of the word-choice. One professor in TESOL, two graduate students in TESOL, who previously belonged to the Japanese program, and one 
Japanese instructor who was teaching Japanese at a different university were the subjects in this pilot study. All the subjects were given the same instructions to sort the words into two to ten piles, and discussed the category names and the words that did not seem to fit this study with the researcher. A couple of category names were changed based on the discussions with the subjects. Finally 39 words were chosen for the card sort (Appendix F). The chosen 39 words were translated into Japanese. Two Japanese graduate students in speech communication translated those words back into English. After that, the researcher discussed the result with the two translators for the improvement of translation.

The final words in both English and Japanese were also tested in this pilot study. Two Japanese graduate students in TESOL and three American instructors who were teaching Japanese were asked to sort cards and rank the five most important cards. The average length of time required for the exercises was about 15 minutes.

\section{Data Collection \#2 (Main Study: Card-sort and Rank-order Exercises)}

All the students and teachers in the Japanese program at NSU and Sylvan University were asked to sort the 39 words into two to ten piles. The 39 words are associated with Japanese teachers in the Japanese classroom. At NSU, 61 American students (including Japanese Americans), 25 international students, twelve Japanese teachers and eleven Japanese students who are enrolled in a Japanese teaching practicum, participated. At Sylvan University, 35 American students (including Japanese Americans), ten international students, and two Japanese teachers were asked to be subjects. The subjects were handed the 39 cards and asked to sort them into groups that they thought 
went together, thinking of the kind of good teachers or the aspects of good teachers they associated with each word or phrase. After they finished the card sorting, they were asked to choose the five most important cards and rank them. Besides card sorting and ranking, all the subjects were free to fill in the demographic data section in the questionnaire. Instruction was given in either English or Japanese. The cards carried the words or phrases in English on the front and the ones in both Japanese and English on the back. The subjects could choose either English or Japanese with English (Appendix H). The card-sorting format was adapted from the knowledge study (Ritchie, 1993).

Data Collection \#3 (Follow-up Study: Interview)

Fifteen American students, one international student, two Japanese students, six Japanese teachers, and one American teacher who previously participated this study were interviewed to discuss the results of this study. The subjects were randomly chosen from volunteers who were available during the last two weeks of July.

The interviews were conducted over 30 minutes to two hours depending on the interviewees' availability. Three group discussions were attempted within four people as well as one to one interviews. The contents of the interviews were as follows:

1. interpretation of word-clustering by hierarchical cluster analysis;

2. interpretation of the dimensions on the MDS-maps;

3. interpretation of the rank-order results;

4. general questions about Japanese classes and teacher-student interaction. 
As far as the interpretation of the dimensions on the MDS-maps, the interviewees were asked to interpret the dimensions before looking at the researcher's interpretation, and to discuss them after looking at the interpretation. For the word-clusterings and the rank-order results, the interviewees were asked to discuss them based on the primary results. These interviews provided more detailed information for further analysis. 
CHAPTER IV

DATA ANALYSIS

The data gathered by the card-sorting task entitled Main Study in chapter III was analyzed by multidimensional scaling (MDS) and hierarchical cluster analysis. Basically three outputs (one MDS map for all the subjects, "Combined Map", another MDS map for American students,"American Map," and the other MDS map for Japanese teachers \& students,"Japanese Map") were analyzed and described. The Combined Map is introduced in the following MDS and hierarchical cluster analysis section, and the American and Japanese Maps are analyzed in comparison. This comparison is not a perfect method of crosscultural comparison because some of the factors are compound, such as student vs. teacher and American and Japanese. However, the purpose of this research is to describe "American students' expectations of Japanese teachers" in the comparison of "Japanese teachers' expectations of themselves." Although there were compounding factors, by adding Japanese students who were enrolled in the Japanese teaching practicum to the Japanese Map as subjects, an attempt to untie the compounded factors was made. This attempt will be discussed in Chapter $\mathrm{V}$ along with the results of the interviews. Next, a rank-order analysis was performed based on the data from the rank-order exercise. The partial result of MDS was continuously used for the rank-order analysis.

In this study, SPSS Inc., Release 4(1990), a statistical program that includes MDS and hierarchical cluster analysis, was applied to analyze the 
data. First, two different versions of SPSS were tried: SPSS for Windows: Professional Statistics, Release 5 (1992) which was made for PC users and SPSS Inc., Release 4 (1990) which was used for mainframe computers. However, lack of memory of the PC computer for an INSCAL analysis in this study was reported by Dr. Robert Fountain at the statistical laboratory. Therefore, only the mainframe program was applied for this study. All of the programs were written by Wes Brenner. Statistical analysis was done with the help of Dr. Fountain.

Multidimensional Scaling (MDS)

The Individual Differences Scaling (INSCAL) model in ALSCAL (SPSS Inc., 1990, p.48) of MDS produced some psychological representations of the subjects. A three-dimensional solution was rendered due to the level of stress of the outputs (maps) and interpretability of the dimensions.

A three-dimensional solution on the combined maps shows stability and interpretability in Figures 1 and 2. All of the 156 subjects' input was used in these maps. 


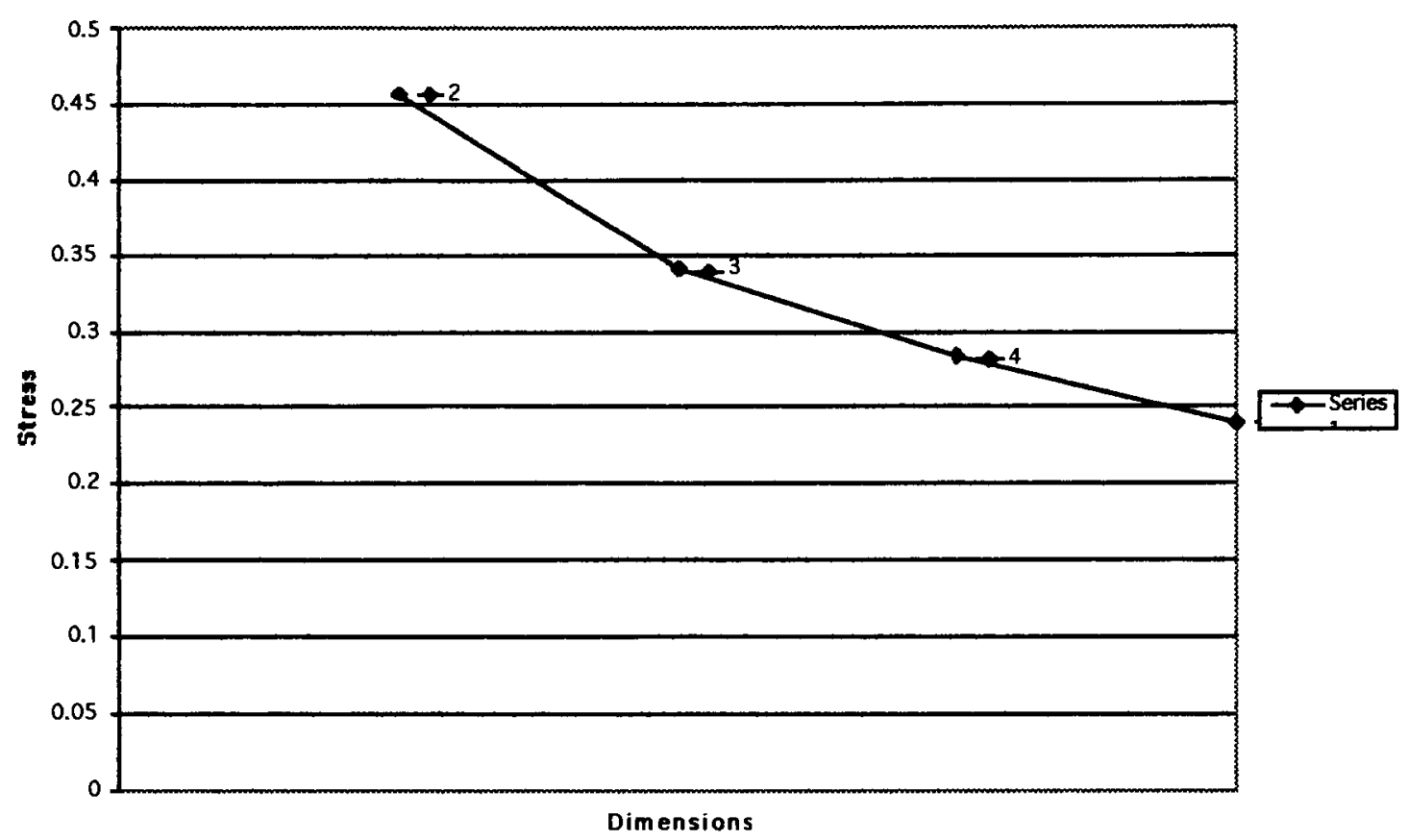

Figure 1.1: stress and dimensions on Combined map

Figure 1.1 shows MDS stress. (see the explanation of MDS stress in Chapter III, p. 25) In this study a three-dimensional solution was chosen for two reasons. First, the amount of stress was drastically reduced from the two dimension (0.458) to the three dimension (0.341). A three-dimensional solution is more stable than a two-dimensional solution because of less stress. After the three dimension, the amount of stress was not drastically diminished either from the three $(0.341)$ to the four dimension $(0.283)$ or from the four (0.283)to the five dimension (0.241). Therefore it is less meaningful to choose either the four or the five dimension.

In addition, the number of clusters could be a clue to decide the number of the dimensions in this study. Based on a hierarchical cluster analysis three 
big clusters were superimposed on spatial maps. (figure 1.2) The consistent appearances of three clusters on all the maps were considered as support of a three-dimensional solution. The interpretation of dimensions is not necessary. However, many researchers try to find meanings in them in order to lend credence to their research. In this study, a two-way interpretation was attempted. (see the explanation of dimensions in Chapter V). 


\section{Dendrogram using Average Linkage(Between Group)}

\section{Rescaled Distance Cluster Combine}

Label

$\begin{array}{llllll}0 & 5 & 10 & 15 & 20 & 25\end{array}$

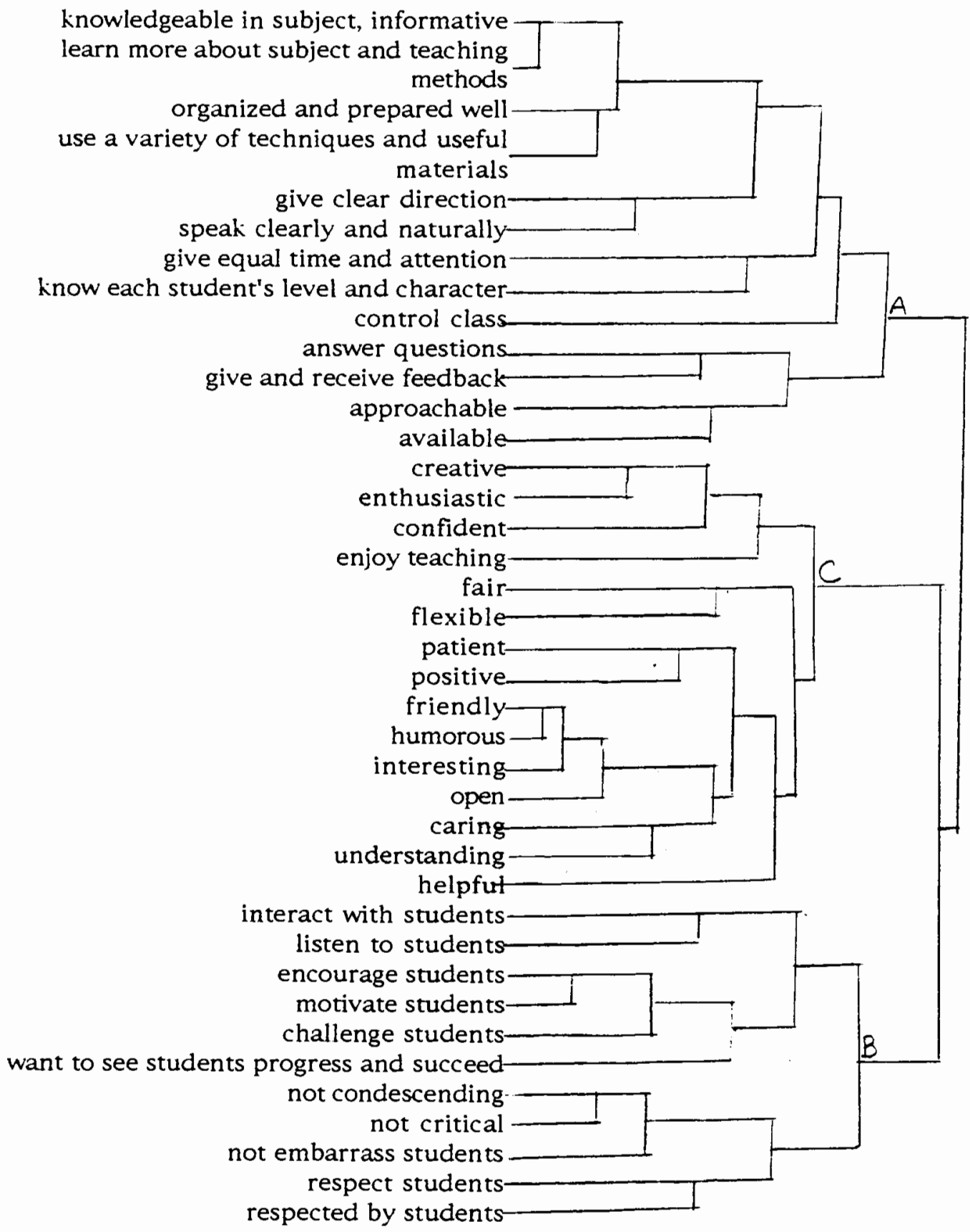

Figure 1.3. Hierarchical cluster analysis for all of the subjects 


\section{Flattened subject weights}

The INSCAI model (Carroll and Chang, 1970) assumes that different subjects perceive stimuli on common sets of dimensions. In this model it is also assumed that "although the stimulus dimensions are common to all subjects they may be differentially important for different individuals" (Dunn-Rankin, 1983, p. 221).

In order to measure how differently American and Japanese subjects used the dimensions, flattened subject weights were examined using a Multivariate Analysis of Variance (MANOVA). The results showed that there was a slight yet not significant difference between the two groups (Significance of $F$ value was .224). Some scholars question its validity: "Hypothesis testing is inappropriate because of lack of independence between the weights." (SPSS, Inc., 1992, p. 212). Therefore, for this study two separate maps were explored although they did not show statistically significant difference.

\section{Hierarchical Cluster Analysis}

The average linkage between group method, one of common clustering methods was applied. This method defines "the distance between two clusters as the average of the distances between all pairs of cases in which one member of the pair is from each cluster" (SPSS Inc., 1992, p. 97).

A hierarchical cluster analysis performed the following dendrogram (figure 1.3). In figure 1.3 , the distances among the big three clusters $(\mathrm{A}, \mathrm{B}, \& \mathrm{C})$ were averaged among all pairs of clusters in each case. 


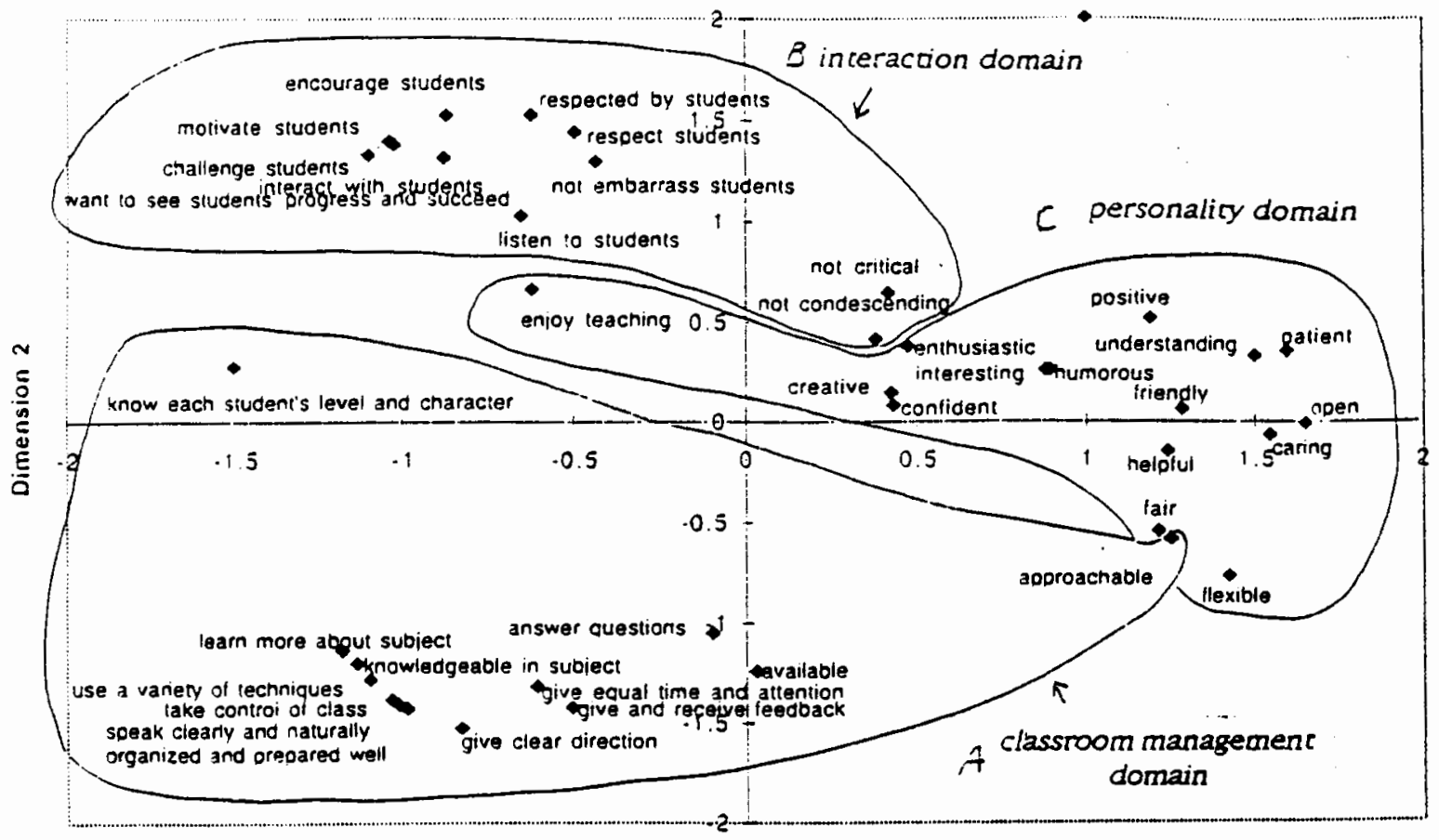

Dimension $i$

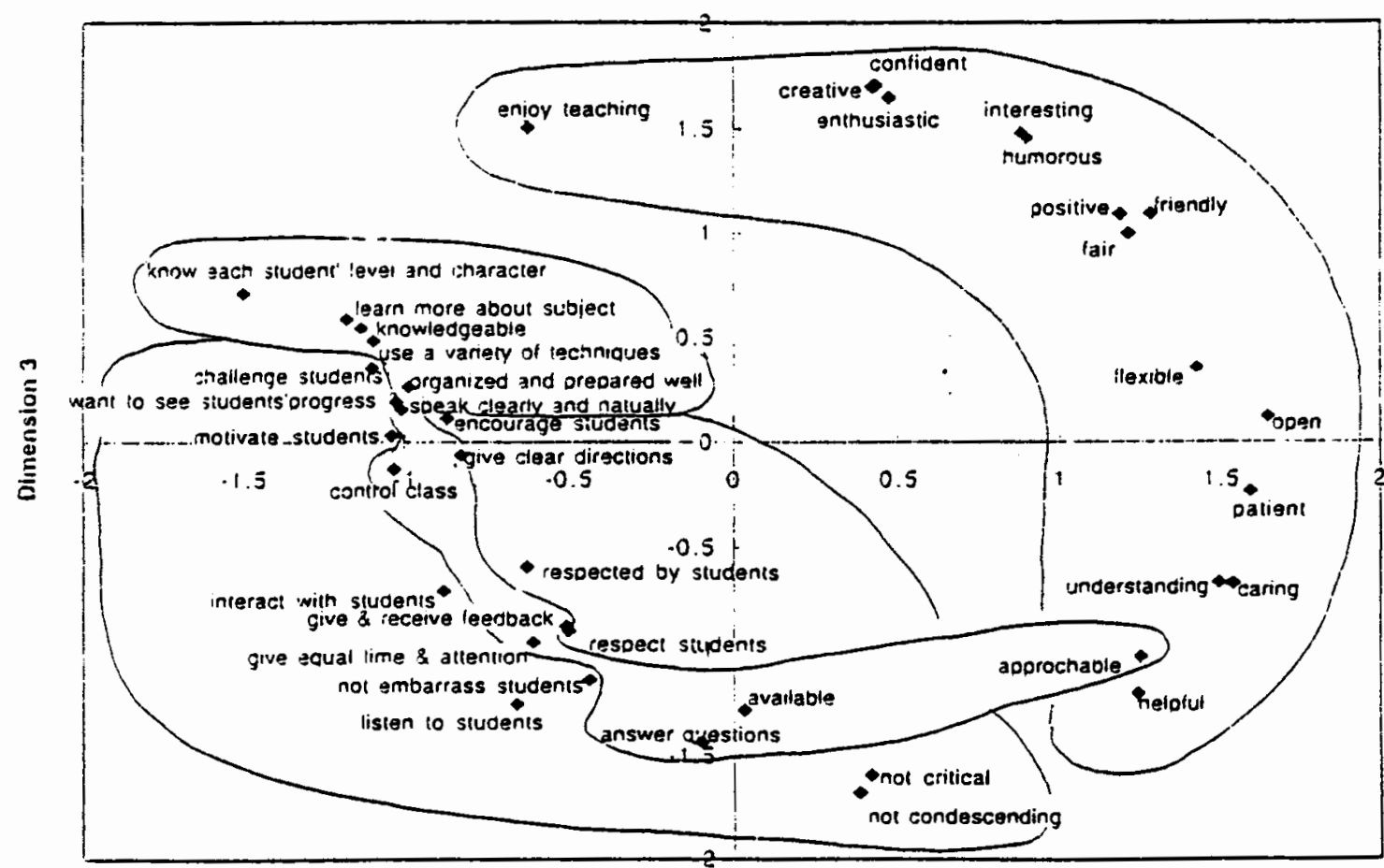

Dimension 1

Figure 1.2 A three-dimensional Combined Map 
The dendrogram shows that there are three big clusters (Cluster A, B, \& C) at around 20 units from the origin. These three clusters were superimposed on the three dimensional Combined Map (figure 1.2). Cluster A seems to retain items which show any kind of Classroom Management. For example, "organized and prepared well," "use a variety of techniques," and give clear direction." Cluster B defines Interaction. For example, "interact with students," listen to students," and "encourage students." Cluster C, on the other hand, appears to carry the characteristics of Personality such as "creative," "friendly," and "humorous." Those three clusters which appeared on both American and Japanese Maps were analyzed in the following section.

Besides the three clusters, the dendrogram shows even more characteristics about grouping. For example, Cluster A and Cluster B flowed into one cluster at around 23 units from the origin. However, Cluster C drew into the end. It showed that Cluster C (Personality) was more independent than Cluster A (Classroom Management) and Cluster B (Interaction), in other words, Cluster A and Cluster B were more related to one another than Cluster C. In addition, cluster B seems to have two sub-groupings (Cluster B-sub A and Cluster B-sub B) at around 17 to 18 units from the origin. Cluster B-sub A looks to have direct interactional items such as "interact with students," 'listen to students," and "encourage students." On the other hand, Cluster B-sub B appears to be more related with 'respect' such as "not condescending," "not critical," "respect students," and "respected by students."

\section{Comparison of American and Japanese Maps}

An INSCAL MDS procedure produced two separate maps: an American Map and a Japanese Map, in a three dimensional space. The sorted 39 words 
were plotted on those maps. The American Map represents the structure of 96 American students' concept of a good teacher in the Japanese classroom. The Japanese Map represents the structure of 25 Japanese subjects' (twelve teachers and eleven students) concept of a 'good teacher' in the Japanese classroom. Even though those two maps had a different number of subjects, they showed almost the same stability (figure $2.1 \& 2.2$ ). Both stress lines showed that they clearly reduced the stress from the dimension twos to the dimension threes (from 0.455 to 0.341 for American Map and from 0.433 to 0.332 for Japanese Map). They indicated that the three-dimensional MDS maps were more meaningful than the two-dimensional ones for both cases. Therefore, two separate maps were produced in a three-dimensional space (figure $3.1 \&$ 3.2).

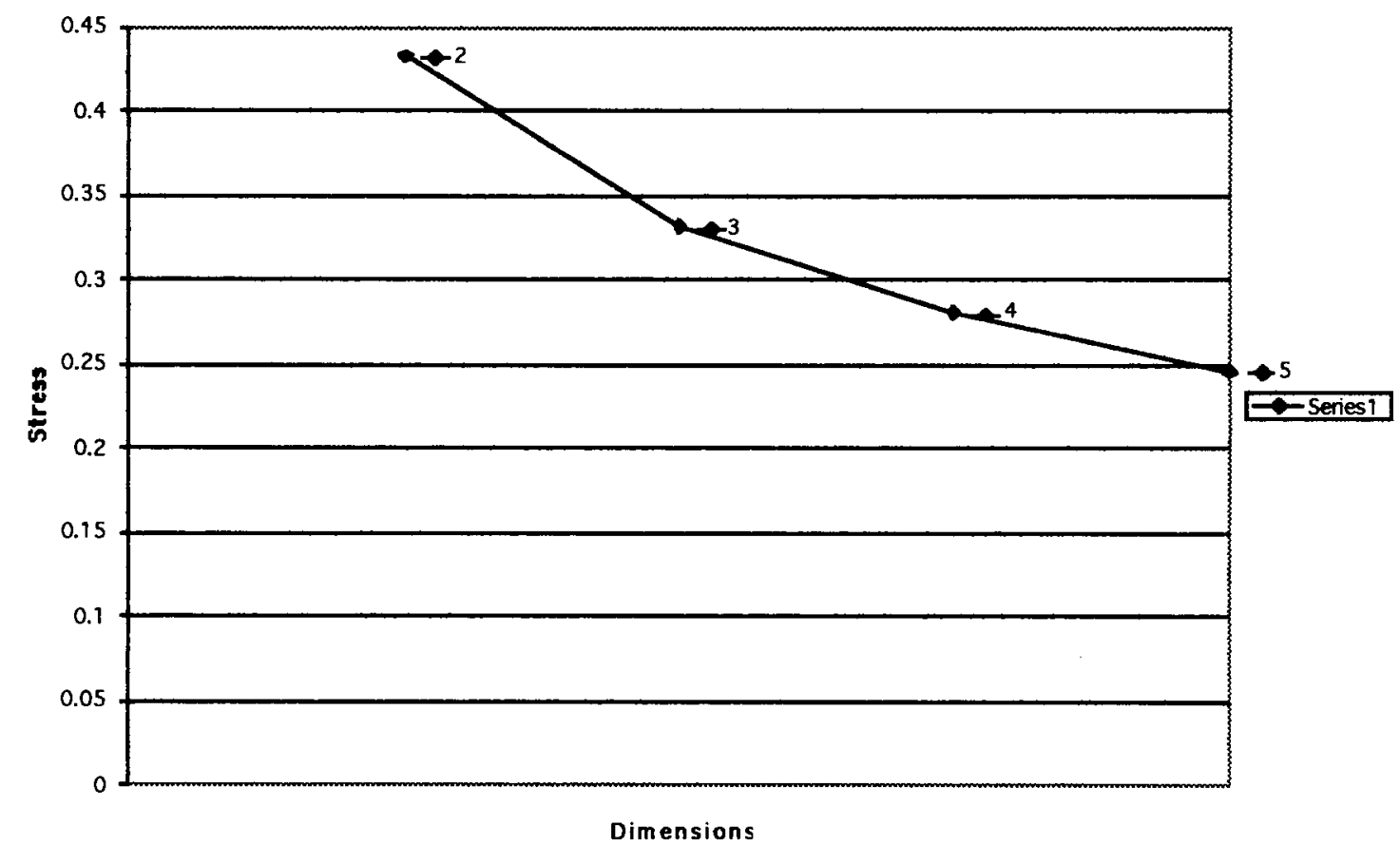

Figure 2.1 MDS stress for American Map. 


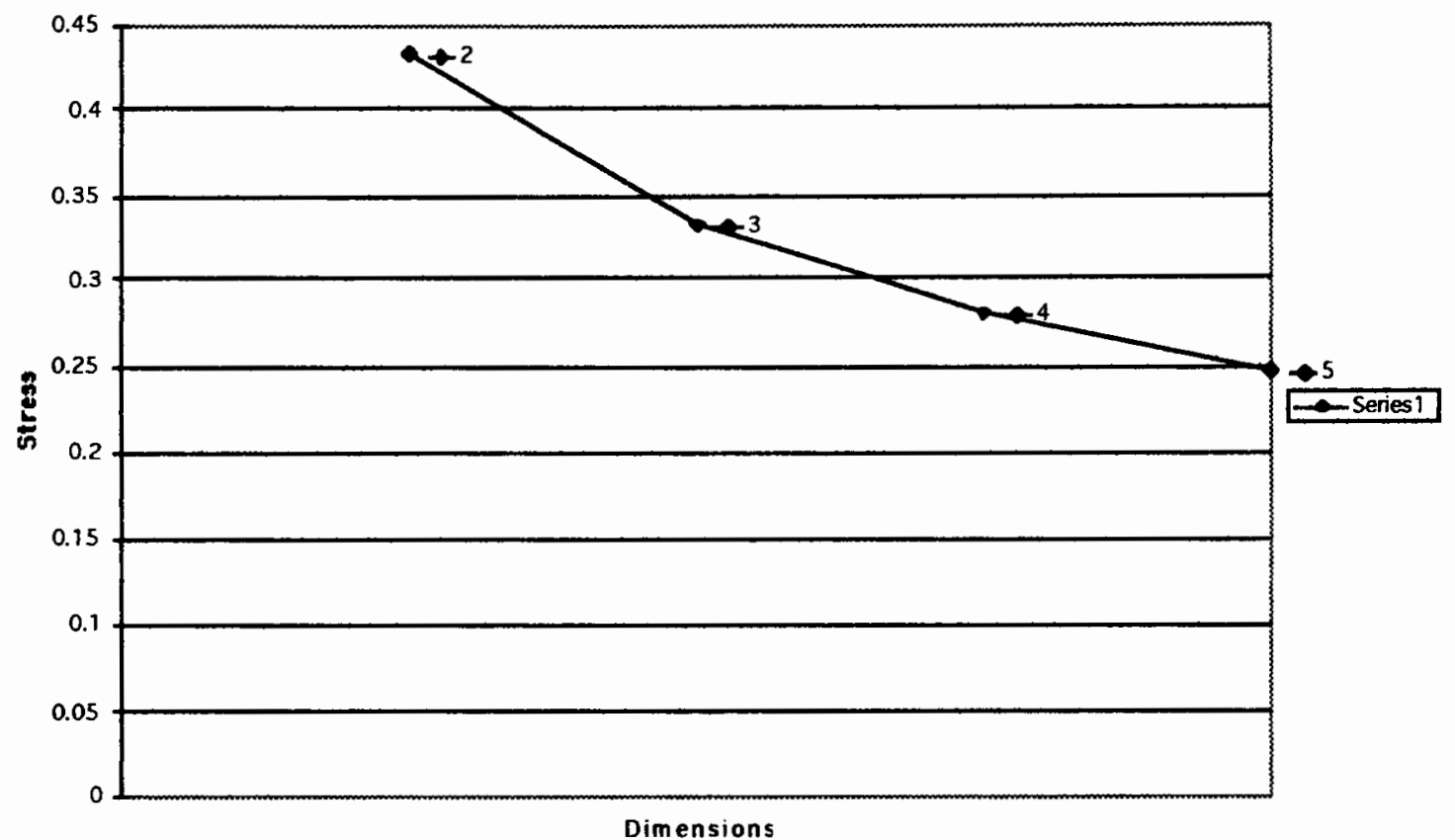

Figure 2.2 MDS stress for Japanese Map 

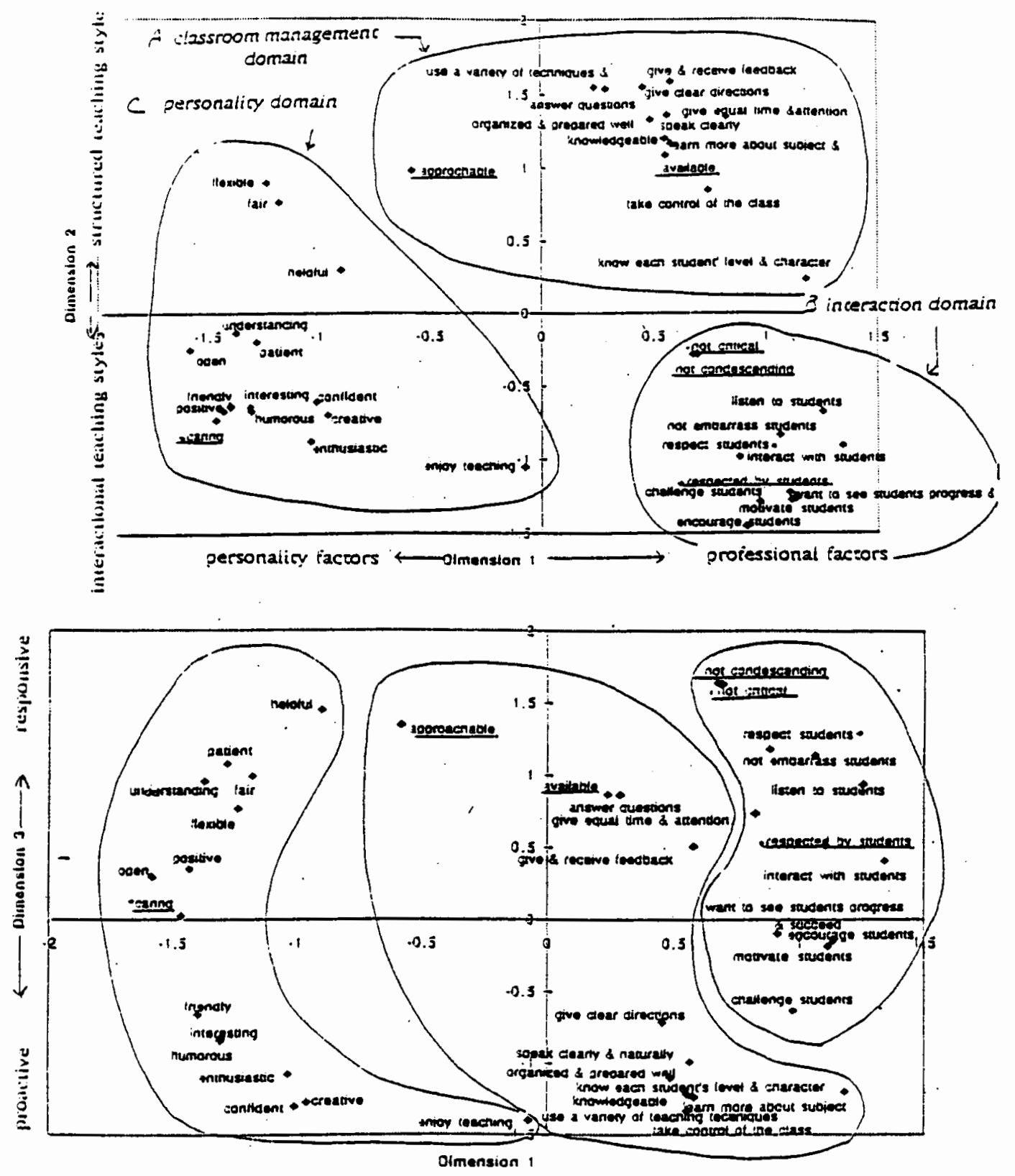

Figure 3.1. American Vap 

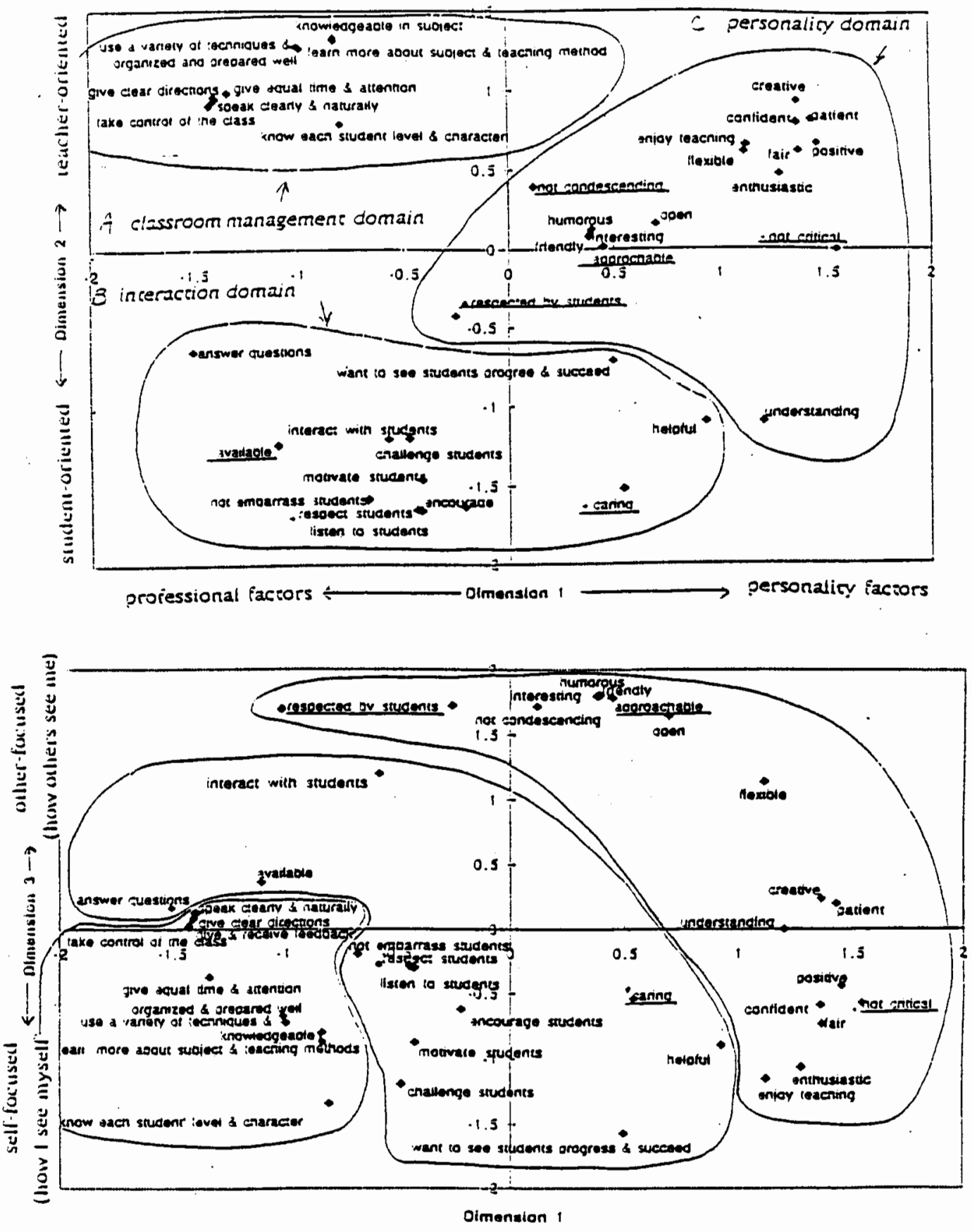

Figure 3.2. Japanese MTap 
Although both sets of maps have the same number of dimensions and content groups, the meanings of the dimensions of each set look slightly different. The interpretation of the dimensions in this chapter were tentative. They were discussed with some of the subjects in the follow-up interviews (see Chapter V).

Both American and Japanese sets of maps have personality factors vs. professional factors as dimension 1. The personality factors include personality characteristics related to being a teacher such as "creative", "friendly" and "confident". On the contrary, the opposite side of dimension 1 shows the professional characteristics related to teaching such as how to interact with students and how to control classroom management. Dimension 2 of the American Map and the Japanese map are different. Americans emphasize interaction between teachers and students; whereas Japanese emphasize role orientation. For example, in Figure 3.1 (American Map), "encourage students," "motivate students," "enjoy teaching" are at the extreme lower edge of dimension 2. These items are associated with an interactional teaching style. In contrast, "give and receive feedback," and "give clear directions" appear at the extreme upper edge of the dimension 2. These item are associated with a structured teaching style. Therefore, dimension 2 was labeled as structured teaching style vs. interactional teaching style. On the other hand, in Figure 3.2 (Japanese Map), "listen to students" and "respect students" are located in the extreme lower edge of dimension 2, whereas "knowledgeable in subject" and "learn more about subject and teaching method" appear at the extreme upper edge of dimension 2. This could suggest that this dimension represents teacher-vs. student-orientation. Dimension 3 is also different for the American Map and the Japanese Map. Dimension 3 for 
the American Map is responsive vs. proactive. Dimension 3 for the Japanese other (how others see me) vs. self (how I see myself). In Figure 3.1 (American Map), "enjoy teaching" and "take control of class (control class)" are located in the extreme lower edge of dimension 3. These items are associated with proactiveness. On the other hand, "not condescending," "approachable," and "helpful" are at the extreme upper edge of dimension 3. These items are associated with responsiveness. Therefore, dimension 3 was labeled as proactive vs. responsive. In contrary, the Japanese Map seems to show the differences between the self- vs. other-focus. In other words, the characteristics of how I see myself as a teacher appear in the lower area such as "want to see students progress and succeed" and "know each student's level and character." On the other hand, the characteristics of how others see me as a teacher appear in the upper side of dimension 3 such as "humorous," "friendly," and "respected by students."

Besides the dimensional differences, the words inside of the content groups appear to be different (figure $4.1 \& 4.2$ ). The Americans sorted "approachable" and "available" into the management domain, whereas the Japanese considered "approachable" as a personality trait, and "available" as an interactional matter. On the other hand, the Americans put "caring" into the personal trait while the Japanese regarded it as one of the concepts representing interaction.

In addition, the Americans sorted "not critical" and "not condescending" into the interactional group, whereas Japanese sorted these words into the personality domain. "Respected by students" was also classified differently by the two groups of subjects. The Japanese classified it as being 
Dendrogram using Average Linkage (Between Groups)

Rescaled Distance Cluster Combine

Label

$\begin{array}{llllll}0 & 5 & 10 & 15 & 20 & 25\end{array}$

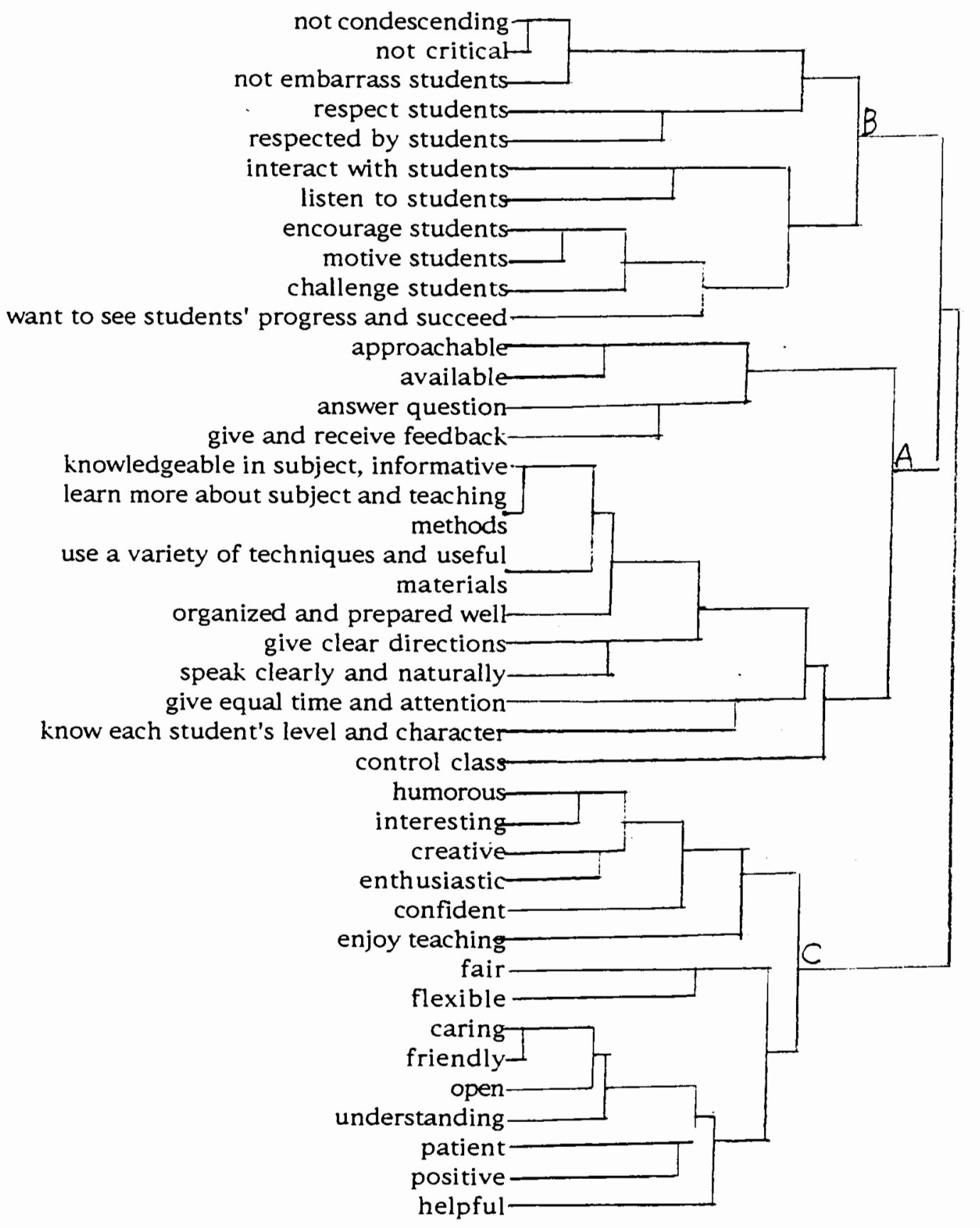

Figure 4.1. Hierarchical cluster analysis for Americans 


\section{Dendrogram using Average Linkage (Between Groups)}

\section{Rescaled Distance Cluster Combine}

Label

$\begin{array}{llllll}0 & 5 & 10 & 15 & 20 & 25\end{array}$

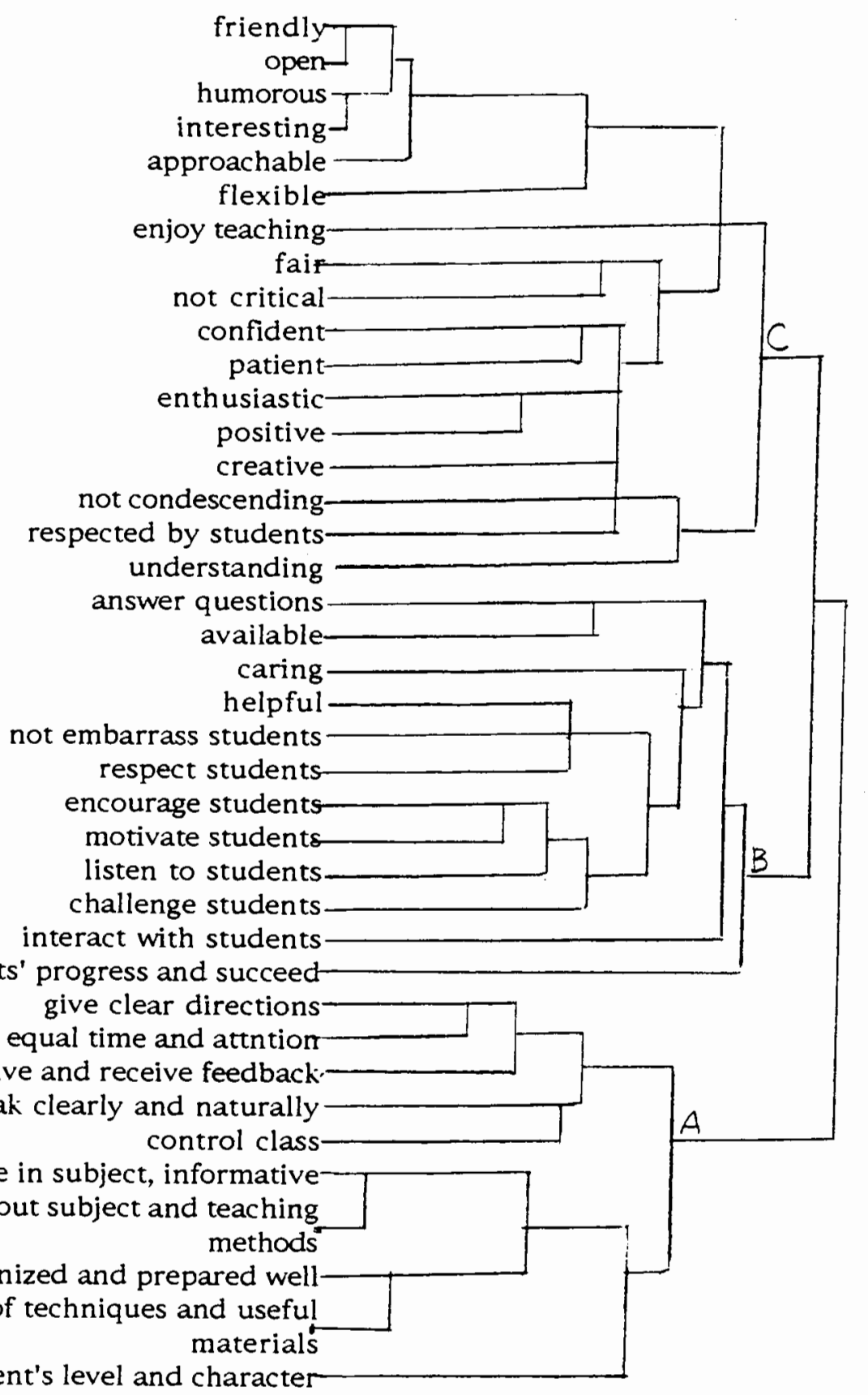

Figure 4.2. Hierarchical cluster analysis for Japanese 
related to personality, while the Americans classified it as being related to interaction.

As stated earlier, both hierarchical clusters showed three big groups (figure $4.1 \& 4.2$ ): Cluster A, B \& C, which were superimposed on MDS maps (figure 3.1 \& 3.2). Cluster A showed Classroom Management as well as Cluster A appeared in Combined-Map. Cluster B appeared to be Interaction, and Cluster C carried the characteristics of Personality as well.

\section{Rank-order Analysis}

Based on the five most important cards that the subjects chose, three rank-order analyses were performed.

First, counts of how many times the individual card appeared among each group were tailled. Next, the weighted rankings were analyzed; the top five cards picked were weighted from one to five points according to the ranking, the unpicked cards were given 22 points which was an average number based on a total of 39 . Those two results were compared and they were almost same. Some of the words were ranked in the different places but the most of the words were ranked in the same places. The results from the second analysis were presented.

The following table shows the results of American students and of Japanese teachers (including both schools). 
Table 3

The rankings of American students and of Japanese teachers

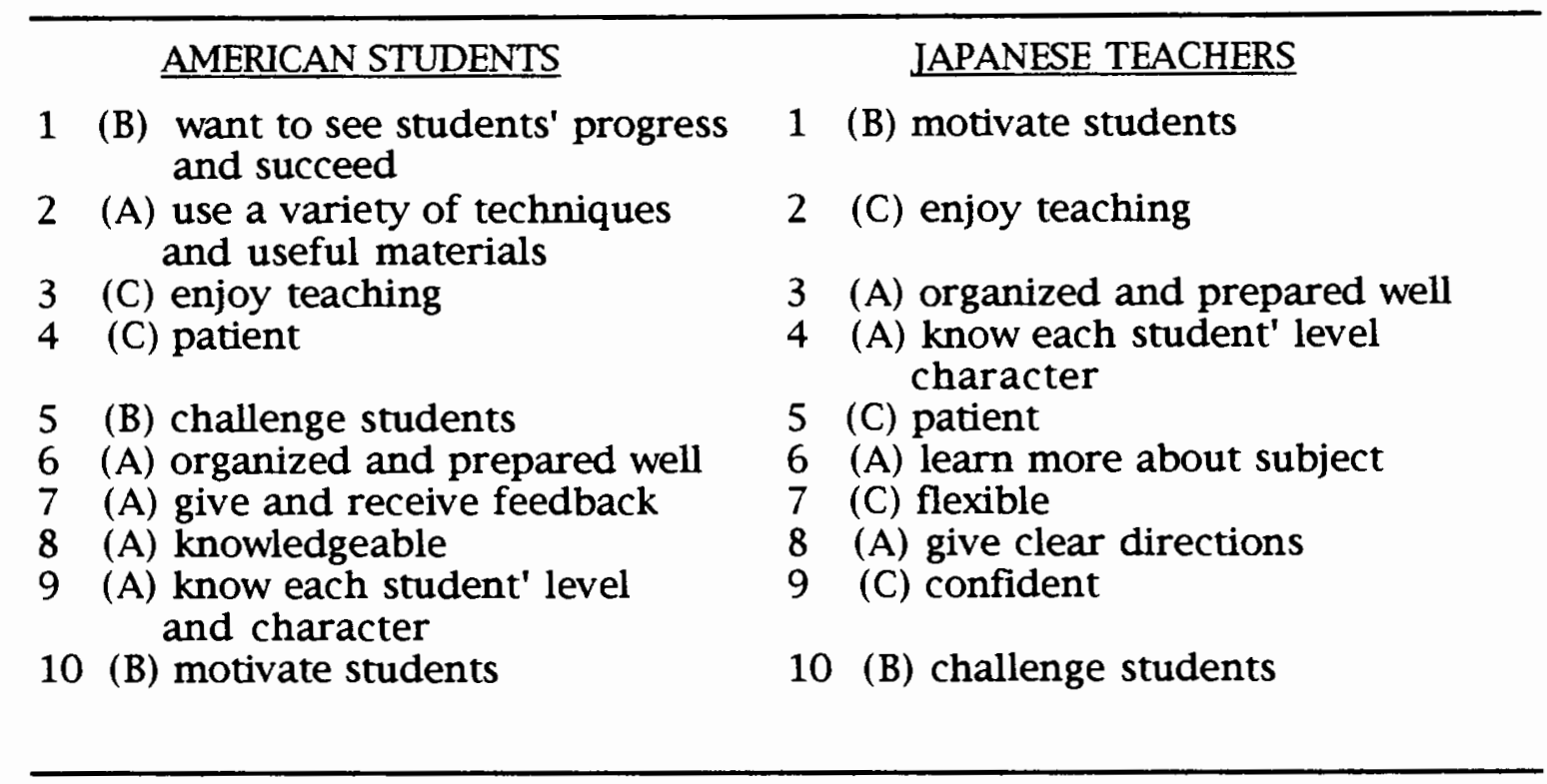

Note. $(\mathrm{A})=$ classroom management domain, $(\mathrm{B})=$ interaction domain, and $(\mathrm{C})=$ personality domain

Out of the top ten rankings, both groups chose six items. They are "enjoy teaching," "patient," "challenge students," "organized and prepared well," "know each student's level \& character," and " motivate students." The two items that American students chose for the most and second important things: "want to see students' progress and succeed" and "use a variety of techniques and useful materials" did not show in the teachers' top ten. On the other hand, the most important thing for Japanese teachers: "motivate students" was located tenth in the American students' ranking. This seems to be very different, and it is important to find out the reasons why they chose the different items. In order to figure out this question, follow-up interviews 
were conducted and the results are presented in the discussion section (Chapter V).

Next, separated rankings of American students were demonstrated according to the school (Table 4).

Table 4

The rankings of NSU and Sylvan University students

$\underline{N S U}$

1 (A) use a variety of techniques and useful materials

2 (B) want to see students progress and succeed

3 (C) patient

4 (A) give and receive feedback

5 (A) organized and prepared well

6 (B) challenge students

7 (A) know each student's level and character

8 (C) enjoy teaching

9 (A) knowledgeable

10 (C) creative
SYIVAN UNIVERSITY

1 (C) enjoy teaching

2 (B) want to see students progress and succeed

3 (A) use a variety of techniques and useful materials

4 (B) challenge students

5 (B) motivate students

6 (A) knowledgeable

7 (B) interact with students

8 (A) organized and prepared well

9 (C) patient

10 (C) enthusiastic

Note. $(A)=$ classroom management domain, $(B)=$ interaction domain, and $(C)=$ personality domain

Out of ten items, seven of them were the same. That means that American students at both schools considered what made a good Japanese teacher in the language classroom in a similar way. However, some of the ranking differences were intriguing to examine in terms of students' expectations. For example, the students at NSU chose "use a variety of techniques" for the most important thing (this was located in the third of Sylvan students' ranking), whereas the Sylvan students picked "enjoy teaching" as the most important 
aspect of Japanese teachers (this was in the eighth of the NSU students'

ranking). "Patient" was also differently placed: the third in the NSU and the eighth in the Sylvan rankings. The follow-up interview to NSU students was done in order to find out more about these differences.

Lastly, a comparison with the ranking of the international students was done to try and make American students' expectations more clear (Table 5).

Table 5

The rankings of international students with comparison of American students

\begin{tabular}{|c|c|c|c|}
\hline & INTERNATIONAL STUDENTS & & AMERICAN STUDENTS \\
\hline 1 & patient & 1 & $\begin{array}{l}\text { want to see students progress } \\
\text { and succeed }\end{array}$ \\
\hline 2 & fair & 2 & $\begin{array}{l}\text { use a variety of techniques } \\
\text { and useful materials }\end{array}$ \\
\hline 3 & organized and prepared well & 3 & enjoy teaching \\
\hline 4 & $\begin{array}{l}\text { want to see students' progress } \\
\text { and succeed }\end{array}$ & 4 & patient \\
\hline 5 & helpful & 5 & challenge students \\
\hline 6 & respect students & 6 & organized and prepared well \\
\hline 7 & motivate students & 7 & give and receive feedback \\
\hline 8 & $\begin{array}{l}\text { know each student' level } \\
\text { and character }\end{array}$ & 8 & knowledgeable \\
\hline 9 & approachable & 9 & $\begin{array}{l}\text { know each student' level } \\
\text { and character }\end{array}$ \\
\hline 10 & $\begin{array}{l}\text { use a variety of techniques } \\
\text { and useful materials }\end{array}$ & 10 & motivate students \\
\hline
\end{tabular}

It seems that the international students chose the cards differently. There were four items that they chose that did not appear in the American students' ranking. They were "fair," "helpful," "respect students," and "approachable." They seemed to choose out of teachers' personality items more than classroom management items. On the other hand, American students picked "enjoy teaching," "challenge students," "give and receive feedback" and 
"knowledgeable." American students seemed to expect Japanese teachers to be good at classroom management rather than expect them to show their good qualities in personality. 
CHAPTER V

INTERVIEWS AND INTERPRETATIONS

Based on the results of the hierarchical cluster, MDS and rank-order analyses (Chapter IV), follow-up interviews were conducted with 25 voluntary subjects who were previously involved with this study. The purpose of the interviews was to confirm the results and to get more detailed information. The interviews had the following four sections:

1. interpretation of word-clustering by hierarchical cluster analysis;

2. interpretation of the dimensions on the MDS-maps;

3. interpretation of the rank-order results;

4. general comments on Japanese classes and teacher-student interaction.

In addition, the first three sections each have a brief summary of the results, and the end of this chapter fully summarizes the interpretation and discussion of the results.

Interpretation of Word-clustering by Hierarchical Cluster Analysis

Summary of the differences between American and Japanese word-

\section{clustering}

The result of hierarchical cluster analysis of both American and Japanese sets of data showed three common clusters: Classroom Management, Interaction, and Personality. However, some of the items in each cluster were located differently. For example, "not critical," "not condescending," and 
"respected by students" were in the Personality cluster on the American Map, whereas they were in the Interaction cluster on the Japanese Map. On the other hand, "caring" appeared in the Personality cluster on the American Map, whereas it was in the Interaction cluster on the Japanese map. "Approachable" and "available" were in the Classroom Management cluster on the American Map, whereas on the Japanese Map "approachable" was in the Personality cluster and "available" in the Interaction cluster.

\section{Interview results}

All of the Japanese teacher and student interviewees agreed that "respected by students" is related to the teacher's personality. In contrast, all of the American teacher and student interviewees strongly stated that "respected by students" should be included in the Interaction cluster and should not be a part of the teacher's personality. Some of the interviewees (both Japanese and American) said that in the United States respect is something that teachers have to make an effort to earn through interaction. On the first day in the classroom, teachers don't receive much respect from students because they don't show enough things to gain students' respect. In contrast, two Japanese students and most of the Japanese teachers said that teachers are naturally respected in the Japanese society because of their role. Two Japanese students especially emphasized this point. They said that respect is one of the core elements in Japanese culture. They have been told that it is very important to respect teachers, parents and the elderly, although it might be argued that the young generation is paying less attention to this. One of the students said that respect is something that belongs to teachers from the beginning. 
Most of the interviewees agreed with the placement of "not critical" and "not condescending," and some of the Americans said that they could be in either in the Personality or Interaction clusters. The one international student considered it to be captured though action or interaction. However, one Japanese student, one Japanese teacher and several American students strongly stated that "not critical" should be in the Interaction cluster. One of the American students said that marking students' errors is necessary as a teacher; however, not being overly critical is very important for a professional teacher. A couple of American students said that not being overly critical shows respect for students, and they provided some examples in which they felt their classmates had been overly criticized by their teachers. They felt that those incidents were caused by the teachers' insufficient professionalism rather than by the teachers' personality.

More than half of the American students perceived "not condescending" as one of the elements of teacher-student interaction. The American teacher and students seemed to have a clear idea about this concept. One American student strongly believed that one of the Japanese teachers was very condescending, providing an example from the classroom. The student felt that way when the teacher corrected one student's error in the class. The teacher did not give the right answer to the student, but let the other students answer, and then came back to the student to say the right answer without any explanation or feedback. It could be part of the miscommunication between students and teachers because it was obvious that the teachers did not intend to act in a condescending way. Another American student, who was listening to this student's example with two other American students, commented that the situation was a consequence of the way of some teachers' techniques. 
"Caring" was emphasized as one of the important elements by most of the Japanese students, teachers, and the international student. "Teachers have to take care of students really well," commented one Japanese student, providing an explanation of the educational situation in Japan; "In Japanese society," which the Japanese student defined as a role-specific society, "the elders are supposed to take care of the youngsters, as do parents for their children, and as do teachers for their students." Another Japanese student emphasized that caring plays an essential role in the Japanese relationship. The student explained that caring was captured in the concept of interaction rather than that of personality, "Japanese people frequently comment on how much a person showed care within a relationship instead of saying how caring the person was." On the other hand, most of the American students considered "caring" as part of a personality description. None of the American teachers or American students emphasized the importance of "caring" through teacher-student interaction. An American teacher who was teaching Japanese explained that there might be a difference in the definition of "caring." American students seemed to consider "caring" as feeling concern, whereas Japanese students tended to interpret this word as taking care of, even though the Japanese translation for this word is "ki ni kakeru" (feel concern). Therefore, this interpretation difference might be part of the difference in the category to which it was assigned.

Both "approachable" and "available" were categorized as Classroom Management by all of the Americans, although some of the American students mentioned that "approachable" could also be part of the Personality cluster. In fact, the "approachable" label appeared toward the left of the personality professional dimension of the American Maps, whereas the "available" label 
appeared toward the right of the personality - professional dimension of the American Maps (figure 3.1). One of the American students said that physical distance between a student and a teacher affected approachability of the teacher. This could be an example of why the American students considered "approachable" as a classroom management skill. In addition, most of the American interviewees related "available" to teachers' office hours. On the other hand, most of the Japanese teachers and students considered "approachable" as a part of personality rather than a classroom management skill. None of the Japanese interviewees mentioned anything about physical space or time in relation to this word. For "available" some of the Japanese mentioned office hours; however, they regarded this concept as interaction with the students rather than a feature of classroom management. One Japanese student pointed out how differences in interpretation influenced the answers of American and Japanese; Americans seemed to interpret "available" and "approachable" in a physical way, whereas Japanese perceived these words in a psychological way.

\section{Interpretation of the Dimensions on the MDS-maps}

\section{Summary of the differences between American and Japanese}

\section{dimensions on the MDS-maps}

The American Map had three dimensions: dimension 1 (personality factors vs. professional factors), dimension 2(interactional teaching style vs. structured teaching style), and dimension 3 (proactive vs. responsive). The Japanese Map also had three dimensions: dimension 1 (personality factors vs. professional factors), dimension 2 (student-oriented vs. teacher-oriented), and dimension 3 (self-focused (how I see myself) vs. other-focused (how others see 
me)). Each dimension showed the subjects' criteria of judgment as to how they sorted the cards.

\section{Interview results}

All of the interviewees agreed with the interpretation of dimension 1 (personality factors vs. professional factors) on both the American and the Japanese Maps. It was obvious that many of the participants had this criteria explicitly in mind when they sorted their cards. The American students also agreed on the interpretation of dimension 2 (structured teaching style vs. interactional teaching style) and dimension 3 (responsive vs. proactive). One American student commented, "No wonder I always argued with one of my classmates in the Japanese classes. She had a high expectation of teachers in the area of structured teaching style, whereas I was concerned how our teachers interacted with the students in the classes." Another American student emphasized the interactional teaching style: "Interaction with students is very important in American culture. This is what I've needed in the Japanese classes." It could be that this emphasis on the interaction is a reflection of the Western value of education which emphasizes communication and discussion between teachers and students.

In contrast, interviewees had different interpretations of dimensions 2 and 3 of the Japanese Map. Two Japanese students strongly agreed with the interpretation of dimension 2 (student-oriented vs. teacher-oriented) emphasizing the hierarchical and role-oriented society in Japan. One Japanese teacher interpreted it as easy teacher vs. strict teacher, and another Japanese teacher thought that this dimension was humanity vs. fairness. However, the rest of the interviewees had some problems with these interpretations. Even though some people did not agree, no one could suggest 
a better interpretation than the original interpretation (other-focused vs. self-focused). Interpretation of the Rank-order Results

\section{Summary of the rank-order results}

NSU students chose "use a variety of techniques and useful materials" as the most important qualities of a good teacher; Sylvan students ranked this quality as third. This label was not ranked in the top ten by Japanese teachers. In contrast Sylvan students chose "enjoy teaching" as the most important qualities of a good teacher. This was ranked eighth by NSU students and second by Japanese teachers. Japanese teachers, on the other hand, picked "motivate students" for the most important quality. This was not chosen in the top ten by the students at NSU and was chosen fifth in importance by the students at Sylvan University.

\section{Interview results}

The top quality for NSU students was "use a variety of techniques and useful materials". Half of the American interviewees said that they could not understand why this was ranked at top; however, it made sense to the rest of the American students. There are two possible explanations for this disagreement. The first explanation may be that the students wanted teachers to use effective techniques and materials such as plots (short dialogues) and visual aids in order to help students memorize (memorization was emphasized at this school). One American student explained the reason why the students' expectation for teachers' techniques received such a high ranking as follows, "It is so easy to compare teachers' techniques because NSU adapts a team teaching [approach] and students have a different teacher everyday. Students 
could have high demand for their teachers easily because of that." The second explanation may be related to some students' preference about the teaching methodology. Some of the students felt that they could not learn well because some of the methodological approaches did not fit their needs.

On the other hand, the Japanese teachers ranked "motivate students" as the most important. Some of the Japanese teachers said that they chose this card based on their responsibility as a teacher. However, they did not seem to have a clear idea about the most practical way to motivate the students. In the comparison between NSU and Sylvan University, several interviewees mentioned that the different teaching methods and school settings might have influenced the differences in rank-order. Since NSU was using a more structured methodology, the characteristics selected by the students' (e.g., "use a variety of techniques and useful materials," "give and receive feedback," or know each student's level and character) leaned toward the structured (dimension 1) and professional (dimension 2) dimension. In contrast, the students at Sylvan University chose items (e.g., "challenge students", "motivate students," or interact with students") from the interactional teaching style area (dimension 2) probably because Sylvan university was using a communicative approach and the students were exposed to much interaction in English and Japanese. Further, because NSU is a rather big public university, most of the NSU students might expect less intimate interaction between teachers and students than the Sylvan students. However, one American student commented that the amount of interaction between teachers and students at NSU was much more than other Japanese programs he was familiar with. He stated that "All the students at NSU can have a lot of opportunity to speak in the class. It never happened to me 
before". This student seemed to define interaction as how many times students practice Japanese with the teachers in the classes, whereas most of the other students seemed to consider interaction as real communication, that is, communication based on their own needs.

\section{General Comments on Japanese Classes and Teacher-Student Interaction}

Several students who were in the first or second year of Japanese classes described the reasons why they felt Japanese teachers were different from American teachers. For example, several students believed that Japanese teachers were more condescending than American teachers. One possible reason mentioned earlier could be the American students' perception of Japanese teachers' style of error correction. Another reason for this perception could be the teachers' style of interaction with their students. Several students commented that "Japanese teachers are teachers inside and outside of the classroom". One American student, who had the experience of teaching English in China, commented that it was rather easy for him to get used to Japanese classes because of his past experience. Another American student said, "I'm trying to enjoy the culture experience in the classroom because I have to learn culture as well as language. So I'm playing with it and making it fun". The other American student said, "Japanese class is hard because you can't just sit and take notes. You have to experience new things at every minute and be always open for the next new thing. You can't be the same person once you learn new things. It is painful. So students need teachers' support in order to make it less painful".

\section{The Summary of the Interpretation and Discussion}


There was a similarity between American and Japanese wordclusterings. Both American and Japanese groups had three clusters: Classroom management, Interaction, and Personality, which appeared on every threedimensional map. It could be that those three clusters were similar for the two cultures. In other words, people had a common framework of categories that determine what makes a good language teacher.

Although American and Japanese people shared a common framework of categories about good teachers, each framework might have different categories. First of all, the concept of respect appears to be culturally different. The key phrase "respected by students" seemed to show the conceptual differences between American and Japanese. As many of the interviewees said, American students tend to think that teachers have to earn respect through interaction with their students, whereas Japanese tend to consider that students should respect their teachers because of their status. This could be the reflection of the differences between the United States. and Japanese societal systems and "self-other" perceptions. Japanese socialization practices are based on social roles. On the other hand, in the U.S. "the person tends to be perceived by self and others as an individual ..." (Hamilton \& Sanders, 1992, p.49) According to some of the interviewees, American students felt that they lost face when they were overly criticized or when the teacher behaved in a condescending way. "Not critical" and "not condescending" could be related to the American concept of respect. This difference might also reflect the difference of interpretation of the dimension 2. Japanese subjects tended to judge in terms of social roles (Japanese subjects had the "teacheroriented vs. teacher-oriented" dimension.). 
The way the people sorted "caring" seemed to show cultural differences between the U.S. and Japan. In a hierarchical society such as Japan, the mother-child and teacher-student relationship leads to the development of their specific roles, that is, mothers and teachers have responsibility to take care of or guide their own children and students, and children and students are supposed to show their respect in return. The differences between American and Japanese word-clustering were summarized in table 6. This could explain why Japanese groups chose "motivate students' as the most important card, whereas American students chose this as the tenth most important in ranking. To Japanese, teachers have a great responsibility to guide and motivate students because of societal rules. On the other hand, in individualistic societies such as the U.S., teachers might have less responsibility because students should motivate themselves also.

Table 6

The differences between American and Japanese word-clusterings

\begin{tabular}{|l|l|l|}
\hline the word or phrase & $\begin{array}{l}\text { which cluster } \\
\text { contained it on the } \\
\text { American maps }\end{array}$ & $\begin{array}{l}\text { which cluster } \\
\text { contained it on the } \\
\text { Japanese maps }\end{array}$ \\
\hline \hline approachable & Classroom Management & Personality \\
\hline available & Classroom Management & Interaction \\
\hline caring & Personality & Interaction \\
\hline not critical & Interaction & Personality \\
\hline not condescending & Interaction & Personality \\
\hline respected by students & Interaction & Personality \\
\hline
\end{tabular}


In addition to cultural differences, the rank-order suggested differences between two schools. The students at Sylvan who had more interaction with teachers chose "enjoy teaching," while the students at the more structured NSU chose "use a variety of techniques and useful materials" as the top ranked items. At the interview, some teachers and students interpreted this as a methodological difference, that is, the school where the students chose "enjoy teaching" for the most important thing was using a rather interactional teaching approach, whereas the other school where the students chose "use a variety of techniques and useful materials" was using a more structured teaching approach. The rankings seemed to reflect what was needed to be successful within the methodological approach of the school. 


\section{CHAPTER VI \\ CONCLUSIONS AND DIRECTIONS FOR FUTURE RESEARCH}

Analysis of the data and interviews based on that analysis in the previous chapters suggested some distinctive features of American students' and Japanese teachers' expectations of Japanese teachers in the Japanese language classroom. There are some similarities and differences between them. Even though the sample number was limited, there are some implications of the findings for the language classroom and for future research.

\section{Conclusions}

There was a major similarity between American and Japanese interpretations of word-clustering. Both groups have three clusters: Classroom management, Interaction and Personality. It could be that both American and Japanese members, who had culturally different orientations, shared a very basic idea about what makes a good teacher.

However, the results also suggested cultural differences. Some key concepts ("respected by students," "not critical," "not condescending," and "caring") and interpretation of the dimension 2 (American Map: interactional vs. structured teaching style, and Japanese Map: teacher-oriented vs. studentoriented) might reflect a difference between the role-specific aspects of Japanese society and the individualistic elements of American society. 
Japanese subjects tended to judge in terms of social roles, whereas American subjects seemed to judge on individual base.

Those conceptual similarities and differences could produce similarities and differences of expectation among students and teachers in the classroom. As Mezirow (1990) argues, the unconscious level of concepts ("habits of expectation") constitute the framework, which is the basic way we interpret new experiences and produce expectations.

In addition, the rank-order seemed to reveal a difference between the two schools. The students at NSU chose "use a variety of techniques", whereas the students at Sylvan University chose "enjoy teaching." This might be a reflection of the different teaching approaches of the two programs. The structured teaching method seemed to produce a more structured expectation, whereas the more interactional teaching method seemed to produce a more interactional expectation.

\section{Implications for the Language Classroom}

The three clusters: Classroom management, Interaction, and Personality could be considered as an important framework of people's perceptions. This could be used as a basis to develop a teacher's manual for classroom management or a teacher's evaluation as a tool. Moreover, by using the 39 key words or phrases, teachers could assess their own strength and weakness in the classes as a self-reflection.

Culture-specifically, Japanese classes that include American students or ESL classes that include Japanese students might consider the role-specific aspects of Japanese society and the individualistic elements of American society. Since the concept of respect seems to differ between cultures, it 
might be helpful for both teachers and students to become aware of this difference. More specifically, Japanese instructors could put more emphasis on interaction with students to build up respect. On the other hand, American students could become more sensitive about social role expectation between teachers and students in Japanese culture.

Both teachers and students should be careful to avoid causing loss of face in order to conduct smooth classroom activities especially in adult education. In order to avoid a cultural crush in the classroom, it is very important for teachers to know their students' expectations, and also to try to bring up students' awareness in the classroom. Japanese teachers might consider how American students can develop a sense of social roles without having their individualistic expectations eliminated. Further, this kind of culture learning component should be included as part of the language program or classroom management.

\section{Limitation of the Study}

Since this study was conducted in an exploratory way, the number of the subjects was restricted. Therefore, conclusions should not be generalized beyond this. Second, the process to confirm interpretation was subjective because of the nature of the interview. Therefore, the names of the cluster and meaning of dimensions need further confirmation. Third, since the researcher herself was a teacher of Japanese, analysis of the results may have been affected by a certain amount of subjectivity. Next, since this study was method-driven, overall theory aspects could be missing on the processes of selection of words, card-sort, interview and interpretation. Lastly, although 
the back-translation for 39 key words or phrases was done, there might be some translation problems that could cause interpretation problems.

\section{Directions for Further Research}

There are some technical suggestions for future research. Since confirmation through interviews was rather subjective, further confirmation of the interpretations using quantifiable methods such as a Likert scale would reduce subjectivity in the study. Moreover, individual differences based on demographic data such as age, major, etc. seem to have some patterns. Those differences need to be explored and compared within the overall structure. More study on multidimensional scaling techniques such as subject weights needs to be done in order to take advantage of new developments in this research tool.

Methodologically, there are some directions for further research. Since this study was exploratory, experimental research can be planned to provide a strong reconfirmation for this research according to the focus of the research (e.g., ethnicity, teaching methodology, etc.). In addition, since the main part of this study was conducted in a quantitative method, it would be interesting to conduct further research using a qualitative method such as ethnography in order to see whether the information matched. 


\section{REFERENCES}

Amir, Y. (1969). Contact hypothesis in ethnic relations. Psychological Bulletin, 71, (5), 319-342.

Amir, Y. (1976). The role of intergroup contact in change of prejudice and ethnic relation. In P. A. Katz (Ed.). Towards the elimination of racism (pp.245-308). New York: Pergamon Press.

Backman, L. (1990). Fundamental considerations in language testing. Oxford: Oxford University Press.

Befu, H. (1986). The social and cultural background of child development in Japan and the United States. In H. Stevenson, H. Azuma, \& K. Hakuta (Eds.), Child development and education in Japan. New York: W.H. Freeman and Company.

Bossert, S. (1979). Tasks and social relationships in classrooms. Cambridge: Cambridge University Press.

Brown, H. (1987). Principles of language learning and teaching. Englewood Cliffs, NJ: Prentice Hall Regents.

Byram, M. (1990). Teaching culture and language: Towards an integrated model. In D. Buttjes \& M. Byram (Eds.), Mediating languages and cultures. Clevedon, Philadelphia: Multilingual Matters.

Centra, J. (1993). Reflective faculty evaluation: Enchanting teaching and determing faculty effectiveness. San Francisco: Jossey-Bass Publishers.

Cousins, S. (1989). Culture and self-perception in Japan and the United States. Journal of Personality and Social Psychology, 56(1), 124-131. 
Damen, L. (1987). A pragmatic approach to intercultural inquiry. Cultural learning: the fifth dimension in the language classroom. Reading, MA: Addison-Wesley.

Dunn-Rankin, P. (1983). Scaling Methods. Hillsdale, N.J. : Lawrence Erlbaum Associates.

Gibson, M. (1987). Punjabi immigrants in an American high school. In (Ed.) G., \& L. Spindler, Interpretive ethnography of education: at home and abroad. Hillsdale, NJ: Lawrence Erlbaum Associates. (pp. 281-310).

Hall, E. (1959). The silent language. Doubleday, Gardencity, New York: Anchor press.

Hamilton, V., \& Sanders, J. (1992). Everyday justice. Yale University Press.

Hofstede, G. (1986). Cultural differences in teaching and learning. International Journal of Intercultural Relations, 10, 301-320.

Jin. L., \& Cortazzi, M. (1993). Cultural orientation and academic language use. In D. Graddol, L. Thompson, \& M. Byram (Eds.), Language and culture. Multilingual Matters LTD. (pp. 84- 97).

Jorden, E. (1992). Broadening our traditional boundaries: The less commonly taught and the truly foreign languages. In W. Rivers (Ed.), Teaching languages in college: Curriculum and content. Lincolnwood, Illinois: National Textbook Company. (pp. 141-156).

Kramsch, C. (1989). New directions in teaching of language and culture. NFLC Occasional Papers, April.

Kramsch, C. (1993). Context and culture in language teaching. Oxford: Oxford University Press. 
Markus, H., \& Kitayama, S. (1991). Culture and the self: Implications for cognition, emotion and motivation. Psychological Review, $\underline{98}(2), 224-$ 253.

Mezirow, J. (1990). Fostering critical reflection in adulthood. San Francisco: Jossey-Bass.

Nelson, G., \& Brown, K. (1992). Hofstede's four dimensional model of cultural differences: Pedagogical applications. Unpublished manuscript, Georgia State University, the Research Office of Georgia State University.

Nieto, S. (1992). Cultural issues and their impact on learning. Affirming diversity: The sociopolitical context of multicultural education. New York: Longman.

Ogbu, J. (1987). Variability in minority responses to schooling: Non immigrants vs. immigrants. Interpretive ethnography of education: at home and abroad. Hillsdale, NJ: Lawrence Erlbaum Associates. (pp. 255- 278).

Peterson, J., Kono, N., Maeda, E., \& Nishishiba, M. (1995). A comparison of the American and Japanese concepts of friendship. Presented at a Regional Conference of Asian Studies on the Pacific Coast. (June 18, 1995).

Rhee, M-J., \& Watanabe, S. (1993, October). Teacher/student role differences in Japanese and Korean Classroom in the U.S. In R. Kubota (Chair), Japanese language in the classroom. Symposium conducted at the joint meeting of the International Studies Association, Western Region and Asian Studies on the Pacific Coast.

Ritchie, D., Baker, R., \& Good, L. (1993). The concept of knowledge in the social structure of reality. Paper submitted to International Communication Association Information Systems Division. 
Rogoff, B. (1981). Schooling and the development of cognitive skills. In H. Triandis, \& A. Heron (Eds..), Handbook of cross-cultural psychology: Developmental psychology, vol. 4. (pp. 233- 294). Boston: Allyn and Bacon.

Rohlen, T. (1983). Japan's high schools. Berkeley: University of California Press.

Rosenberger, N. (1992). Japanese sense of self. New York: Cambridge University Press.

Scarcella, R., \& Oxford, R. (1993). The tapestry of language learning. Boston: Heinle \& Heinle Publishers.

Schiffman, S., Reynolds, M., \& Young, F. (1981). Introduction to multidimensional scaling: Theory, method, and applications. New York: Academic Press.

Scribner, S., \& Cole, M. (1981). The psychology of literacy. Cambridge, MA: Harvard University press.

Spindler, G., \& Spindler, L. (1987). Interpretive ethnography of education: at home and abroad. Hillsdale, NJ: Lawrence Erlbaum Associates.

SPSS Inc. (1992). SPSS for windows: Professional statistics, release 5. Chicago: SPSS Inc.

Stingler, J., \& Stevenson, H. (1992). How Asian teachers polish each lesson to perfection. American Educator, spring, 12-21,43-47.

Strevens, P. (1987). The nature of language teaching. In H. Long \& J. Richards (Eds.), Methodology in TESOL: A book of readings. Newbury House Publishers. (pp. 10-24). 
White, M. (1987). The Japanese educational challenge: a commitment to children. New York: The free Press.

Young, F. (1987). Multidimensional scaling: history, theory, and applications. Hillsdale, N.J. : Lawrence Erlbaum Associates. 
APPENDIX A

A program of a $39 \times 39$ matrix for each of 156 subjects

FILE: LOWERMAT FORTRAN

VM/ESA Conversational Monitor System

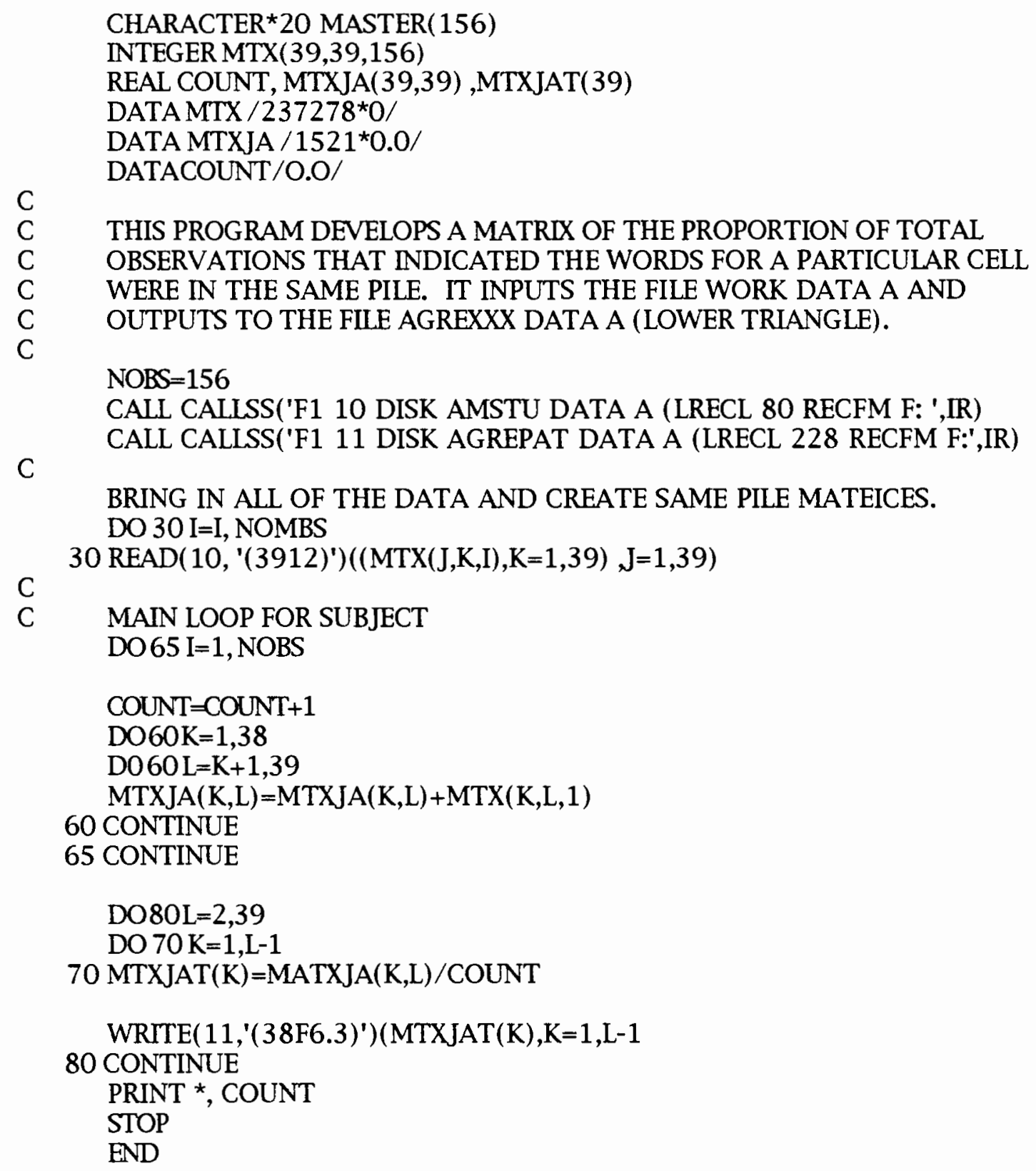




\section{PROGRAM DESCRIPTION}

NAME:

AUTHOR:

INPUT:

VARIABLES:

PROCESS:

OUTPUT:
A program of a $39 \times 39$ matrix for each of 156 subjects

Wes Brenner

File name is AMSTU. It has sequential 80 character fixed length records, with one $39 \times 39$ matrix for each of 156 subjects. There are 39 words that each subject put into groups. The rows and columns are labeled with the same list of words. For any particular cell, if the subject grouped the word for the row with the word for the column there is a 1 , otherwise it contains a 0 . (The upper left to lower right diagonal cells all contain l's.)

MTX 3-dimensional internal matrix

COUNT Accumulated number to control number of output records. Same as number of subjects.

MTXJA 39 X 39 internal table.

MTXJAT 1 X 39 internal table for computed results

NOBS Number of subjects

For each set of cells in the upper diagonal half of each subject's matrix that have the same row and column number, add the l's together and divide by the number of subjects. The result for each cell will be between 0 and 1 , and reflect the proportion of subjects who grouped the two indicated words together.

File name is AGREPAT. It is a diagonal half of a single $39 \times 39$ matrix containing a value between 0 and 1 in each cell. 

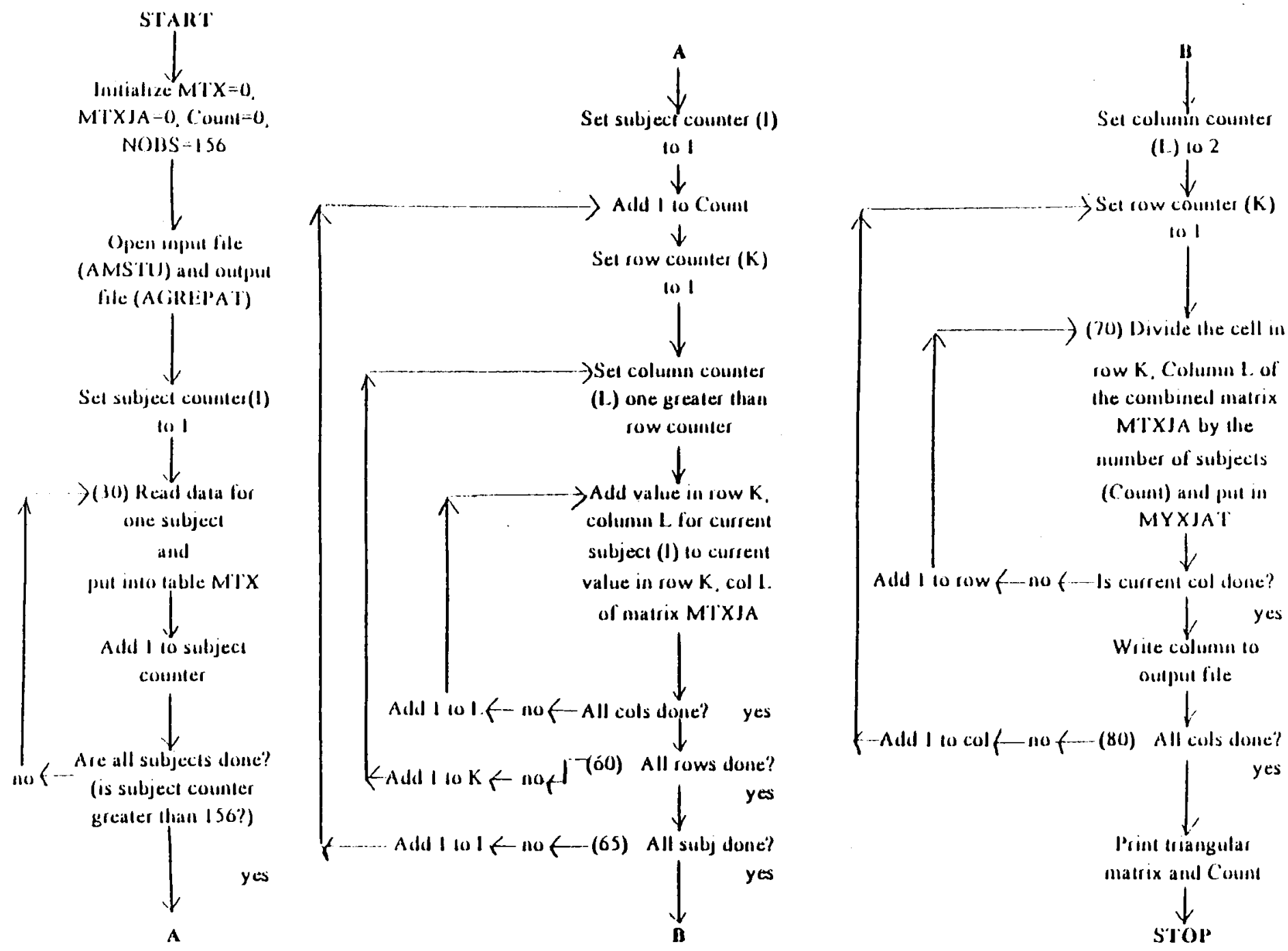


\section{APPENDIX B}

\section{Student Questionnaire}

Please reflect on your native Japanese teachers and complete the following sentences in any way that you wish (One answer for each line provided). If you can not think of five sentences for each question, you don't have to fill in all of them.

1. A good teacher should be:

(Characteristic/Quality)

(Characteristic/Quality)

(Characteristic/Quality)

(Characteristic/Quality)

(Characteristic/Quality)

2. A good teacher should not be:

(Characteristic/Quality)

(Characteristic/Quality)

(Characteristic/Quality)

(Characteristic/Quality)

(Characteristic/Quality)

3. A good teacher should: 
(Action)

(Action)

(Action)

(Action)

4. A good teacher should not:

(Action)

(Action)

(Action)

(Action)

(Action)

5. Good teachers would like /want to:

(Action)

(Action)

(Action)

(Action) 
(Action) 
APPENDIX C

\section{Teacher Questionnaire}

Think about your role as a teacher and complete the following sentences $\underline{\text { in }}$ any way that you wish (One answer for each line provided). If you can not think of five sentences for each question, you don't have to fill in all of them. 先生としての自分の役割を考えて、自分の好きなように次の文を完成させてください。(一行に つき、ひとつ答えを入れてください。）もし考えつかなければ25行全部書く必要はありません。 英語か日本語のどちらかで書いてください。

1. A good teacher should be:

(Characteristic/Quality)

(Characteristic/Quality)

(Characteristic/Quality)

(Characteristic/Quality)

(Characteristic/Quality)

2. A good teacher should not be:

(Characteristic/Quality)

(Characteristic/Quality)

(Characteristic/Quality)

(Characteristic/Quality)

(Characteristic/Quality)

3. A good teacher should: 
(Action)

(Action)

(Action)

(Action)

(Action)

4. A good teacher should not:

(Action)

(Action)

(Action)

(Action)

(Action)

5. Good teachers would like / want to:

(Action)

(Action)

(Action)

(Action) 
(Action) 
APPENDIX D

The number of the subjects

who participated in the questionnaire

Students

\begin{tabular}{|l|l|l|l|l|l|}
\hline & American & Intl & Sub (I) & Total (II) & $\%$ (I/II) \\
\hline 1st year & 24 & 4 & 28 & 39 & 71.8 \\
\hline 2nd & 13 & 3 & 16 & 24 & 66.7 \\
\hline 3rd & 9 & 2 & 8 & 21 & 52.4 \\
\hline 4th & 4 & 4 & 11 & 10 & 80.0 \\
\hline Total & 50 & 13 & 63 & 94 & 67.0 \\
\hline
\end{tabular}

Teachers

\begin{tabular}{|l|l|l|l|l|l|}
\hline & $\begin{array}{l}\text { Japanese } \\
\text { individual }\end{array}$ & numbers & $\begin{array}{l}\text { American } \\
\text { individual }\end{array}$ & numbers & $\begin{array}{l}\text { Total } \\
\text { numbers }\end{array}$ \\
\hline 1st year & $\begin{array}{l}\mathrm{a}, \mathrm{b}, \mathrm{c}, \mathrm{d}, \mathrm{e}, \mathrm{f}, \mathrm{g}, \\
\mathrm{h}, \mathrm{i}, \mathrm{j}\end{array}$ & 10 & $\mathrm{~A}$ & 1 & 11 \\
\hline 2nd & $\mathrm{a}, \mathrm{b}$ & $(2)^{\star}$ & $\mathrm{B}, \mathrm{C}$ & 2 & $(2)^{\star}$ \\
\hline 3rd & $\mathrm{k}, \mathrm{l}$ & 2 & & & 2 \\
\hline 4th & $\mathrm{k}, \mathrm{l}$ & $(2)^{\star}$ & & & $(2)^{\star}$ \\
\hline Total & & $12(4)^{\star}$ & & 3 & $15(4)^{\star}$ \\
\hline
\end{tabular}

*The numbers of ( ) show the numbers of the teachers who taught more than one year-level. For example, the total number of the Japanese teachers was twelve but the four of twelve teachers were teaching the different year-level classes.

The alphabets represented individual teachers: the small letters (a-1) were Japanese and the capitalized ones $(\mathrm{A}-\mathrm{C})$ were American. 
APPENDIX E

The list of words or phrases that were chosen by American students

\begin{tabular}{|c|c|c|}
\hline No. & $\begin{array}{l}\text { How many people } \\
\text { chose the word or } \\
\text { phrase }\end{array}$ & $\begin{array}{l}\text { words or phrases that appeared in the } \\
\text { questionnaire }\end{array}$ \\
\hline 1 & 23 & patient \\
\hline 2 & 20 & helpful \\
\hline 3 & 17 & encourage students \\
\hline 4 & 13 & knowledgeable in subject \\
\hline 5 & 11 & creative \\
\hline 6 & 10 & prepare well \\
\hline 7 & 9 & not rude \\
\hline 8 & 9 & understanding \\
\hline 9 & 8 & not critical \\
\hline 10 & 7 & enthusiastic \\
\hline 11 & 7 & fair \\
\hline 12 & 6 & friendly \\
\hline 13 & 6 & flexible \\
\hline 14 & 6 & humorous \\
\hline 15 & 6 & answer questions \\
\hline 16 & 6 & organized \\
\hline 17 & 5 & approachable \\
\hline 18 & 5 & rushful \\
\hline 19 & 5 & condescending \\
\hline 20 & 4 & explaining grammar, things etc. \\
\hline 21 & 4 & not boring \\
\hline 22 & 4 & continue to learn \\
\hline 23 & 4 & enjoy teaching (willing to teach) \\
\hline 24 & 4 & interesting \\
\hline 25 & 4 & involved (with students) \\
\hline 26 & 6 & not rigid \\
\hline 27 & 4 & not frustrated \\
\hline 28 & 3 & caring \\
\hline 29 & 3 & challenging \\
\hline 30 & 3 & clear: speech \& direction \\
\hline 31 & 3 & competent \\
\hline 32 & 3 & open-minded \\
\hline 33 & 3 & not dull \\
\hline 34 & 3 & not embarrass students \\
\hline 35 & 3 & give \& receive feedback \\
\hline 36 & 3 & informative \\
\hline 37 & 3 & not judge \\
\hline 38 & 3 & kind \\
\hline
\end{tabular}




\begin{tabular}{|l|l|l|}
\hline 39 & 3 & open \\
\hline 40 & 3 & positive \\
\hline 41 & 3 & not pressure students \\
\hline 42 & 3 & not overbearing \\
\hline 43 & 3 & be respected \& respect students \\
\hline 44 & 3 & speak clearly \\
\hline 45 & 3 & not stick to the rule \\
\hline 46 & 3 & use a variety of techniques \\
\hline 47 & 3 & motivate students \\
\hline 48 & 2 & animated \\
\hline 49 & 2 & available (in and out of classroom) \\
\hline 50 & 2 & not belittle students \\
\hline 51 & 2 & not biased \\
\hline 52 & 2 & concern \\
\hline 53 & 2 & confident \\
\hline 54 & 2 & consistent \\
\hline 55 & 2 & develop rapport \\
\hline 56 & 2 & energetic \\
\hline 57 & 2 & exciting \\
\hline 58 & 2 & give examples \\
\hline 59 & 2 & give equal time and attention \\
\hline 60 & 2 & not humiliate students \\
\hline 61 & 2 & not insult \\
\hline 62 & 2 & interact with students \\
\hline 63 & 2 & laugh with students \\
\hline 64 & 2 & not lazy \\
\hline 65 & 2 & optimistic \\
\hline & & \\
\hline
\end{tabular}


The list of words or phrases that were chosen by Japanese teachers

\begin{tabular}{|l|l|l|}
\hline No. & $\begin{array}{l}\text { How many people } \\
\text { chose the word or } \\
\text { phrase }\end{array}$ & $\begin{array}{l}\text { words or phrases that appeared in the } \\
\text { questionnaire }\end{array}$ \\
\hline \hline 1 & 10 & fair (in grading) \\
\hline 2 & 5 & prepare well \\
\hline 3 & 4 & take strong initiative \\
\hline 4 & 4 & know students' level and character \\
\hline 5 & 4 & listen to students \\
\hline 6 & 3 & help \\
\hline 7 & 3 & supportive \\
\hline 8 & 3 & motivate students \\
\hline 9 & 3 & open-minded \\
\hline 10 & 3 & patient \\
\hline 11 & 3 & respect students \\
\hline 12 & 3 & learn \\
\hline 13 & 2 & approachable \\
\hline 14 & 2 & interesting \\
\hline 15 & 2 & cheerful \\
\hline 16 & 2 & empathetic \\
\hline 17 & 2 & enthusiastic \\
\hline 18 & 2 & give feedback \\
\hline 19 & 2 & guide students \\
\hline 20 & 2 & do not ignore students \\
\hline 21 & 2 & interact with students \\
\hline 22 & 2 & make class comfortable \\
\hline 23 & 2 & organize \\
\hline 24 & 2 & want to see students' progress \\
\hline 25 & 2 & sensitive to students \\
\hline 26 & 2 & encourage students \\
\hline & & \\
\hline
\end{tabular}


APPENDIX F

\begin{tabular}{|c|c|c|c|c|}
\hline & words or phrases & $\begin{array}{l}\text { the words } \\
\text { that were } \\
\text { chosen } \\
\text { only by } \\
\text { American }\end{array}$ & $\begin{array}{l}\text { the words } \\
\text { that were } \\
\text { chosen } \\
\text { only by } \\
\text { Japanese }\end{array}$ & $\begin{array}{l}\text { the words } \\
\text { that were } \\
\text { included in } \\
\text { the } \\
\text { literature }\end{array}$ \\
\hline 1 & answer questions & $\star \star * *$ & & \\
\hline 2 & approachable & & & \\
\hline 3 & $\begin{array}{l}\text { available (in and out of } \\
\text { classroom) }\end{array}$ & & & * \\
\hline 4 & caring & * & & * \\
\hline 5 & challenge students & $\star * *$ & & \\
\hline 6 & confident & $\star \star \star *$ & & \\
\hline 7 & creative & $\star \star \star *$ & & \\
\hline 8 & encourage students & & & \\
\hline 9 & enjoy teaching & $\star \star \star *$ & & \\
\hline 10 & enthusiastic & & & * \\
\hline 11 & fair & & & * \\
\hline 12 & flexible & $\star \star \star \star$ & & \\
\hline 13 & friendly & * & & * \\
\hline 14 & give and receive feedback & & & * \\
\hline 15 & give clear directions & & & \\
\hline 16 & give equal time and attention & $\star * *$ & & \\
\hline 17 & helpful & & & * \\
\hline 18 & humorous & * & & * \\
\hline 19 & interact with students & & & \\
\hline
\end{tabular}




\begin{tabular}{|c|c|c|c|c|}
\hline 20 & interesting & & & * \\
\hline 21 & $\begin{array}{l}\text { know each student's level and } \\
\text { character }\end{array}$ & & $* * *$ & \\
\hline 22 & $\begin{array}{l}\text { knowledgeable in subject, } \\
\text { informative }\end{array}$ & & & * \\
\hline 23 & $\begin{array}{l}\text { learn more about subject and } \\
\text { teaching methods }\end{array}$ & & & \\
\hline 24 & listen to students & & $* * *$ & \\
\hline 25 & motive students & & & \\
\hline 26 & not condescending & $* * *$ & & \\
\hline 27 & not critical & $\star \star *$ & & \\
\hline 28 & not embarrass students & & & \\
\hline 29 & speak clearly and naturally & & & * \\
\hline 30 & open & & & \\
\hline 31 & organized and prepared well & & & * \\
\hline 32 & patient & & & \\
\hline 33 & positive & & & \\
\hline 34 & respect students & & & * \\
\hline 35 & respected by students & $* * *$ & & \\
\hline 36 & control class & & * & * \\
\hline 37 & understanding & * & & * \\
\hline 38 & $\begin{array}{l}\text { use a variety of techniques and } \\
\text { useful materials }\end{array}$ & & & * \\
\hline 39 & $\begin{array}{l}\text { want to see students' progress } \\
\text { and succeed }\end{array}$ & & * & * \\
\hline
\end{tabular}

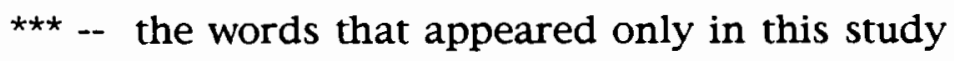


APPENDIX G

The words or phrases on the cards

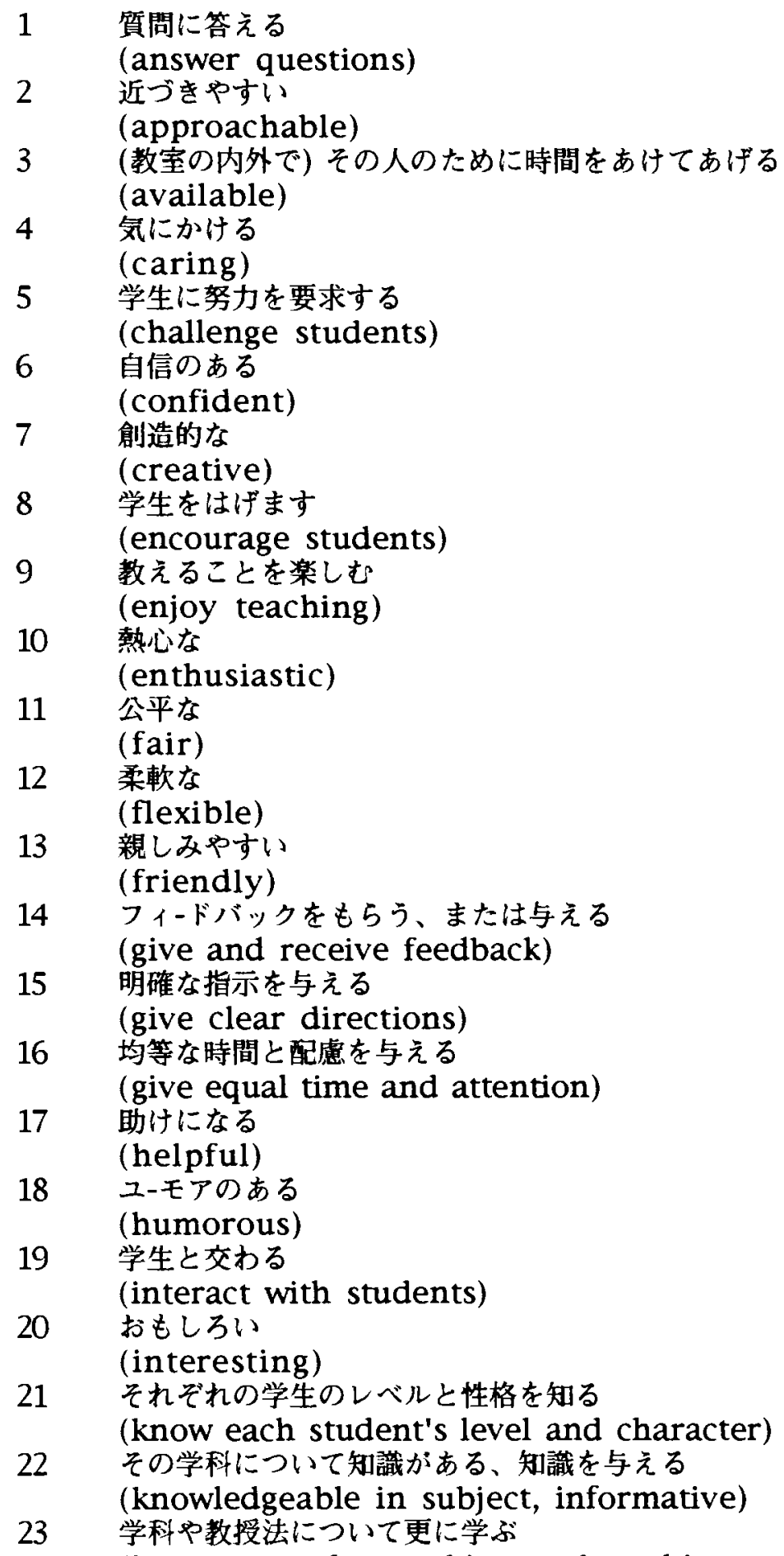


24 学生に耳をかたむける

(listen to students)

25 学生をやる気にさせる (motivate students)

26 (自分の地位や権力を意識して高くとまったり) 恩着せがましくしない

27 批判的でない (not critical)

28 学生を(人前で) 当感させない (not embarrass students)

29 はっきりと自然に帮す

30 オープンな (open)

31 よく整理して、準備している (organized and prepared well)

32 怒耐強い (patient)

33 前向きな (positive)

34 学生の意志を尊重する (respect students)

35 学生に尊敬されている (respected by students)

36 クラスを取りまとめる (control class)

37 理解のある (understanding)

38 変化に富むテクニックや役に立つ教材を使う (use a variety of techniques and useful materials)

39 学生の進歩と成功をみたい

(want to see students' progress and succeed) 
APPENDIX H

The instructions for card-sorting

[for students]

Now pick up the cards that were handed out. Each of the words or phrases on these cards has to do with students' expectations of Japanese teachers in the Japanese language classes. Please sort the cards into groups that you think go together, thinking of the kind of good teachers or the aspect of good teachers you associate with each word or phrase. There is no right or wrong way to sort these cards! I'm interested in how you think about them. Use between two and ten groups, and put however many cards you want into each group. There is one thing that you cannot do: Don't put words together just because they are nouns, adjectives, or verb phrases, or because of any other grammatical similarity.

You will notice an identification number printed on the left hand corner of each card. When you have sorted the cards to your satisfaction, assign a letter, A through J, to each group of words, and enter the numbers for the cards in each group in the spaces on the corresponding line, below. Please be sure to use a separate line for each group.

A.

B.

C.

D.

E.

F.

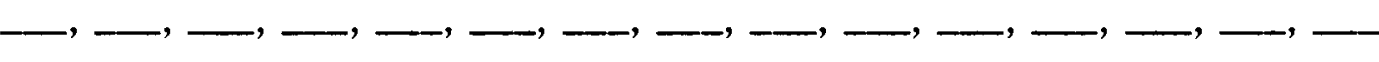

B.

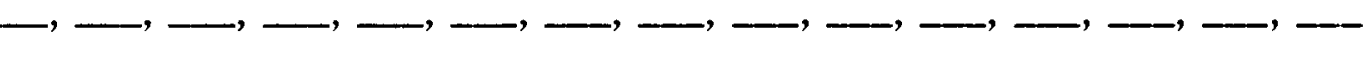

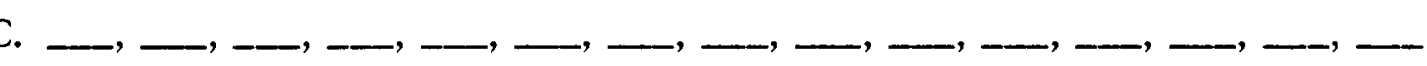
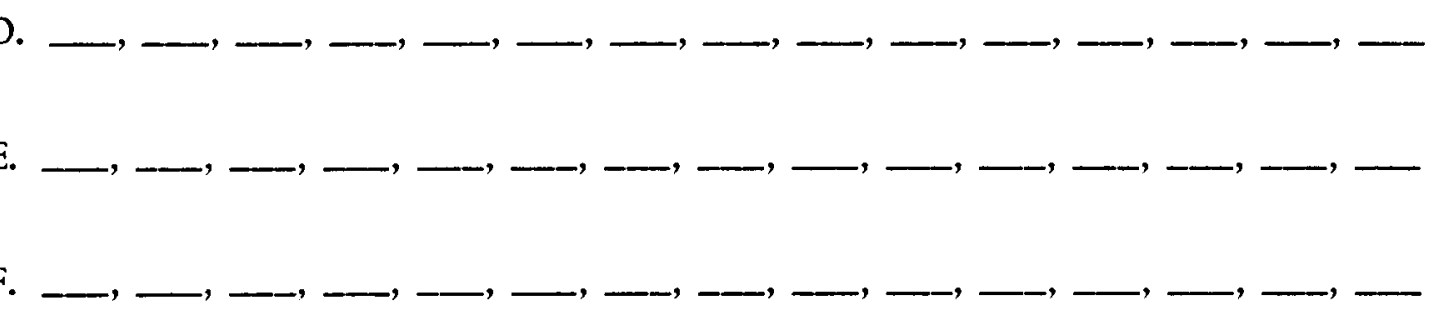
G.
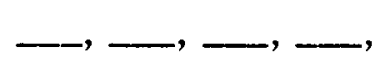

$\longrightarrow$
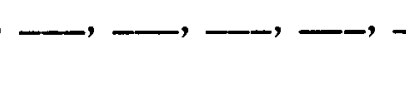

H.

I.
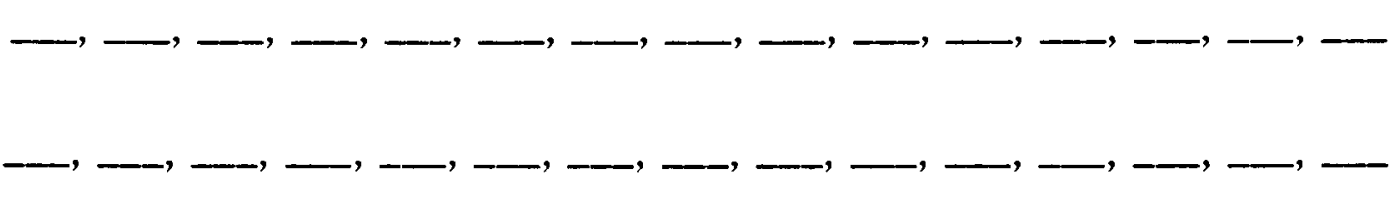

$\mathrm{J}$.

Now I would like to know which descriptions you think are most important for Japanese teachers in the Japanese language classes.

Please choose the 5 most important descriptions from the cards that you sorted, and rank them. Please write the numbers of the five cards that you chose. (Please write the most important one for $<1>$ the second most important one for $\langle 2\rangle$, the third important one for $\langle 3\rangle$, and so forth.)

$$
\begin{aligned}
& <1> \\
& <2> \\
& <3> \\
& <4> \\
& <>>
\end{aligned}
$$

Thank you very much for your help. If you would like to make any comments or suggestions, feel free to write here. 
Thank you for participating. Please note that the information you provide here could be linked to what you have said on the Student Questionnaire. Feel free not to respond to any of the following questions.

\section{Student Personal Information}

Write in or circle the appropriate answer.
1.Age:
2.Male
Female

3.Major:

4.What year language classes are you taking? $101 \quad 102 \quad 201 \quad 202 \quad 302 \quad 402$ 5.Have you studied Japanese before NSU? Yes No

If so, where and how long?

6. Do you speak with somebody whose first language is Japanese outside of the classroom? Yes No

If so, who is she/he?

$\begin{array}{ll}\text { your wife/husband your mother/father } & \text { your relative } \\ \text { your roommate your girlfriend/boyfriend } & \text { your friend }\end{array}$
the other (

If so, how frequently do you speak Japanese with that person?
a. I live with the person and speak Japanese very frequently.
b. Very frequently (almost everyday).
c. Frequently (a couple of times a week).
d. Sometimes (a couple of times a month).
e. Rarely.

7.Have you been to Japan? Yes No

If so, why and how long?

8.Are you familiar with the Jorden textbook(s)? Yes No

If so, how long have you used the textbook(s)?

9.What is your first language?

10. Have you learned any other foreign language? Yes No 
If so, what is (are) the language(s)?

11. Have you studied any of the Japanese cultural practices? Yes No (Tea ceremony, Calligraphy, Flower arrangement, Karate, etc.)

If so, what is it and how long?

12. What is your nationality?

\section{[for teachers]}

配られたカードを手に取ってください。これらのカードには、日本語のクラスの日本人の先生に 対する学生の期待に関連した言葉が書かれています。それぞれの言葉に関連した日本㻬の先生 について考えながら、それらのカードを関連があると思われる言葉ごとにまとめてグループに分 けてください。カードを分けるのに間違った、あるいは正しい方法というのはありません。カー ドは日本語と英語で書かれていますので、わからない時は、日本望と英害の両方を参照して カードソートしてください。2個から10個までのグループを作って、必要だと思われるカードをい くつでもそれでれのグル-プに入れてください。ただし、次のことはしないでください。言葉 を名詞、形容詞、動詞、またはそのほかの文法的な違いによって、分けないでください。

カードの左端に番号がついています。自分の納得いく様にカードを分け終わったら、それでれの グループをAから」と考えて、下の対応する線にカードの番号を書いてください。各グループ、そ れぞれに別の行を使ってください。
A.
B.
C.
D.
E.
F.
G.
H.
I.
J. 
次に、日本語のクラスの日本人の先生にとってもっとも大切だと思われるカードを選んでくだ さい。カードソートに使ったカードの中から、もっとも大切だと思われるもの5つを選んで、順位 をつけてください。そしてあなたが選んだ5つのカー゙のの番号を書いてください。（最も大切な ものをく1> に、2番めに大切なものを<2> に、3番めに大切だと思われるものを $<3>$ (i...)

$<1>$

$<>$

$<3>$

$<4>$

$<5>$

こ協力ありがとうございます。もし何かお気づきになられたことがありましたら、 ここに打青きください。 
下記のアンケートに答えてくださいるたは通当なものを○で囲んでくだされ
1. 年令:
2. 男性
女性

3. 専攻:

4. 学位: 大学生 大学終了 大学院生修士号

博士過程博士号

5. 現在、日本語のクラスを教えていますか。はい防 もしそうでしたら、それは何年生のクラスですか 一年生 二年生 三年生 四年生 その他( )

6. どのくらい日本語を教えていますか。どこで教えていますか、またはどこで数えました 加。

7. どのくらいアメリカに滞在していますか。

8. 英語を母国語とする人と話しますか。 はわ $(\downarrow) え$ そのかたはどなたですか。

$$
\begin{aligned}
& \text { 夫/妻父/母親踧少公メイト } \\
& \text { ボーイフレンド/ガールフレンド＼cjkstart友人 その他（） }
\end{aligned}
$$

そのかたとどのくらい英語を話しますか。(アルファベットを○で囲んでください)

a. その人といっしょに住んでいて、とてもよく英語を話す。

b. とてもよく話す。(ほとんど毎日)

c. よく話す。(週2、3回程度)

d. 時々話す。(月2、3回程度)

e. めったに話さない。

9. Japanese: The spoken language by Jorden \& Noda (テキスト)を使っています か。 いい いいえ
もしそうでしたら、どのくらい長く使っていますか。 
106

10.あなたの母国語は何ですか。

11、日本国籍ですか。はいいえ 